This manuscript is a peer-reviewed preprint submitted to EarthArXiv that will appear in the United States Geological Survey (USGS) volume Volcanic and Seismic Hazards of Northern Harrat Rahat, Saudi Arabia. The final published version of this manuscript will be available via the 'Peer-reviewed Publication DOI' link on the manuscript's webpage. Please feel free to contact any of the authors, we appreciate all feedback!

\title{
Mantle earthquakes in recently thinned Neoproterozoic lithosphere: Harrat Lunayyir, Saudi Arabia
}

\author{
By Alexander R. Blanchette, ${ }^{\mathrm{a}, \mathrm{,}}$, Simon L. Klemperer ${ }^{\mathrm{a}}$, Walter D. Mooney ${ }^{\mathrm{a}, \mathrm{b}}$, and Hani M. Zahran ${ }^{\mathrm{c}}$
}

aDepartment of Geophysics, Stanford University, Stanford, CA 94305, United States

bUnited States Geological Survey, Earthquake Science Center, Menlo Park, CA 94025, United States

'Saudi Geological Survey, Jeddah 21514, Saudi Arabia

${ }^{*}$ Corresponding author email address: ablanch@stanford.edu

\begin{abstract}
We use earthquake geothermometry, measured heat flow, and structural constraints from P-wave receiver functions to model the thermal evolution of the lithosphere beneath Harrat Lunayyir. We suggest that the lithosphere thinned to its present $60-\mathrm{km}$ thickness in a second stage of lithospheric thinning at 15-12 Ma following initial Red Sea extension at $27 \mathrm{Ma}$. Harrat Lunayyir is an active volcanic field located in the Arabian Shield $>150 \mathrm{~km}$ east of the Red Sea rift axis. In the lithospheric mantle beneath Harrat Lunayyir we locate 64 high-frequency earthquakes at depths of $42-48 \mathrm{~km}$, all with $\mathrm{m}_{\mathrm{L}} \leq 2.5$. These brittle-failure earthquakes must have nucleated at relatively low temperatures, based upon global maximum nucleation depths and temperaturedependent-deformation experimental results. Therefore, the mantle earthquakes show that the upper-mantle lithosphere is not in thermal equilibrium with the shallow $(60 \mathrm{~km})$ underlying asthenosphere. Our thermal modeling indicates that the lithosphere beneath Harrat Lunayyir thinned to its current $60-\mathrm{km}$ thickness at $12 \pm 2$ Ma, as constrained by thermal modeling of: (1) surface heat-flow; (2) the depth to the mid-crustal brittle-ductile transition, and (3) the depth to the upper-mantle brittle-ductile transition.
\end{abstract}

\section{Introduction}

Earthquakes within the continental mantle lithosphere are sufficiently rare as to excite intensive study. These events are mostly found within zones of continental convergence or subduction (Chen \& Molnar, 1983; Sloan \& Jackson 2012; Schulte-Pelkum et al., 2019), beneath non-magmatic rift zones (Yang \& Chen, 2010), and possibly also plate-boundary strike-slip faults (Inbal et al., 2016). The seismicity of the Arabian plate is highly concentrated along its borders (Youssef, 2015), and the seismic quiescence of the Arabian interior conforms to the very definition of a craton (Mooney et al., 2012). Precambrian shields typically have sufficiently thick and cold lithosphere that mantle earthquakes could occur, but their exceedingly low strainrates, including those within Arabia (Reilinger \& McClusky, 2011), cause mantle earthquakes to be particularly rare beneath shields (Frohlich et al., 2015). Volcano-seismicity, with mantle and lower-crustal earthquakes likely caused by early-stage pooling and mixing of asthenospheric melt at the base of or within the lower-crust (McCausland et al., 2017), should also be rare in cratons, including Arabia, given their low heat-flow (Gosnold, 2011). However, here we report 64 high-frequency (brittle-failure) earthquakes within lithospheric mantle beneath the western margin of the Arabian Shield. 


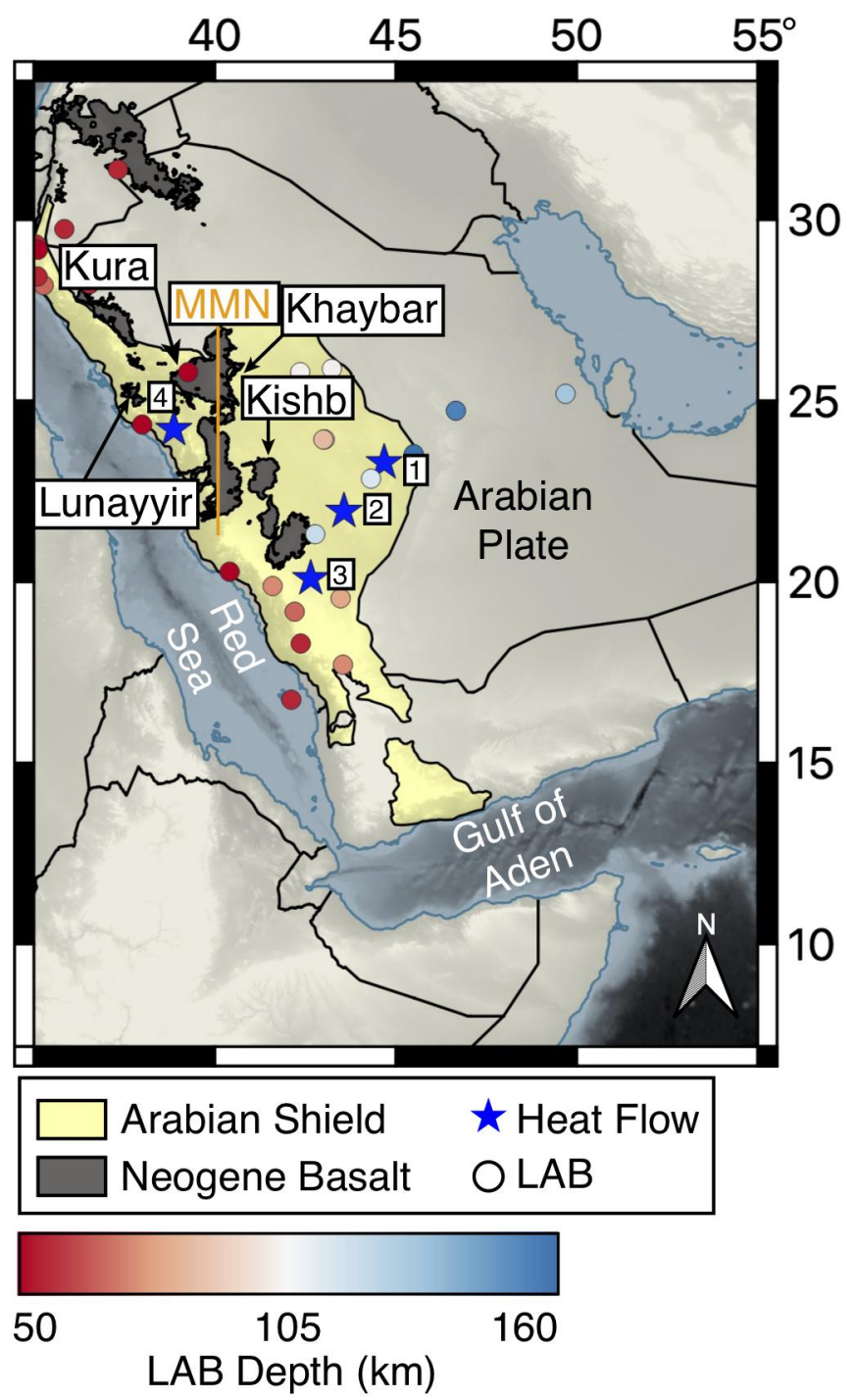

Figure 1. Map of Saudi Arabia. Harrats Khaybar, Kishb, Kura, and Lunayyir are labeled. Blue stars mark surface heat-flow measurements within the Arabian Shield from the global heat-flow database (Gosnold, 2011) and are labeled as follows: $1=$ SAU002 $\left(34 \mathrm{~mW} / \mathrm{m}^{2}\right), 2=\operatorname{SAU} 003\left(43 \mathrm{~mW} / \mathrm{m}^{2}\right), 3=$ SAU004 $\left(44 \mathrm{~mW} / \mathrm{m}^{2}\right), 4=\operatorname{SAU} 006\left(50 \mathrm{~mW} / \mathrm{m}^{2}\right)$. Colored circles indicate estimates of depth to LAB from Hansen et al. (2007). MMN = MakkahMadinah-Nafud line.

Understanding of Red Sea rift history has evolved beyond early 'two-stage' models for the Red Sea that include two stages of ocean spreading (at 41-34 Ma and at 5-4 Ma; Girdler \& Styles, 1974) or two pulses of 'initial' or 'early stage' rifting (at $24 \mathrm{Ma}$ and at 21-25 Ma; Omar \& Steckler, 1995) to widespread acceptance that the first formation of Red Sea rift basins was in Late Oligocene time (28-24 Ma) (Bosworth, 2015). Our two-stage rifting model distinguishes the Late Oligocene initiation from a mid-Miocene second stage of major lithospheric thinning culminating at $12 \pm 2 \mathrm{Ma}$ and has much in common with a recent theoretical model that identifies two-stage evolution as a common feature of successful rifts (Brune et al., 2016). In this latter model, lithosphere that is initially cold and thick, hence strong, begins to rift slowly with full plate-separation rates $<10$ $\mathrm{mm} / \mathrm{yr}$. As the lithosphere is extended further, it is thinned and heated from below, leading to a nonlinear decrease in lithospheric strength. This thinning and weakening - if it can outpace conductive cooling of the lithosphere - initiates a second, much faster phase of rifting. This second stage of rifting has a profound effect upon the thermal state of rifted margins and hence the depths of their brittle-ductile transitions.

Harrat Lunayyir is a volcanic field along the western edge of the Arabian Shield, east of the Red Sea rift margin (Figs. $1 \& 2$ ), beneath which we re-located 64 earthquakes that occurred within the lithospheric mantle during 2014. We assume heat flow within the interior of the Arabian shield at $\sim 30-40 \mathrm{~mW} / \mathrm{m}^{2}$ is representative of thermal conditions prior to rifting, whereas a measurement near Harrat Lunayyir is $\sim 50 \mathrm{~mW} / \mathrm{m}^{2}$ (Gosnold, 2011). Here we model the thermal evolution of the lithosphere, using constraints provided by depths of earthquake nucleation and measured surface heat flow, to bound the time when the Red Sea rift transitioned from the first slower stage of rifting to the second faster stage. 


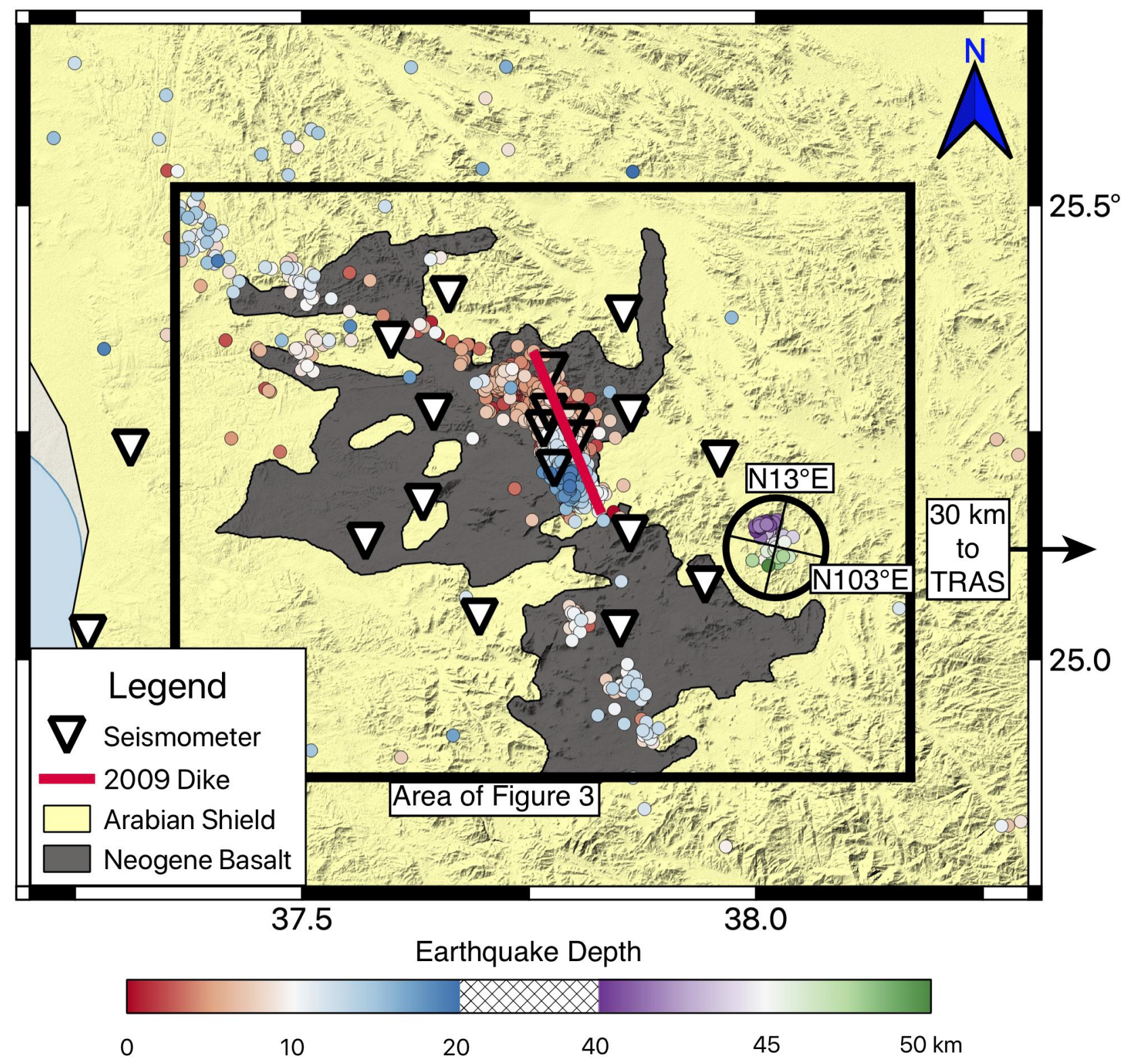

Figure 2. Map of Harrat Lunayyir. Showing the surface trace of the 2009 dike intrusion (Pallister et al., 2010), the local seismometer array, upper-crustal seismicity (depths color-coded red to blue), and mantle seismicity from 2014 (depths color-coded purple to green). The arrow points to the easternmost station of the array (TRAS), $30 \mathrm{~km}$ beyond the map. The black box bordering Harrat Lunayyir outlines the extent of our common conversion point cube (Fig. 3). Direction lines within the circle around the mantle earthquakes show the strike of the event cluster $\left(\mathrm{N} 103^{\circ} \mathrm{E}\right)$ and its dip direction $\left(\mathrm{N} 193^{\circ} \mathrm{E}\right)$. The cluster has a dip of $43^{\circ}$ from the vertical.

\section{Geologic/Geophysical Framework}

The Arabian-Nubian Shield was assembled via repeated terrane accretion during the Neoproterozoic (Stoeser \& Camp, 1985). After 500 Myr of relative stability the shield began to break apart due to impingement of the Afar Plume at $30 \mathrm{Ma}$, which triggered extension first in the Gulf of Aden and then in the Red Sea by 25 Ma (Stern \& Johnson, 2010). Initiation of shear on the Dead Sea transform in the middle Miocene and penecontemporaneous initiation of full ocean spreading in the Gulf of Aden facilitated a second phase of Red Sea rifting with rotation of extension from rift-normal (WSW-ENE) to Dead Sea transform-parallel (SSWNNE) at $11 \pm 2 \mathrm{Ma}$ (Bosworth et al., 2015) as constrained geodetically (Reilinger \& McClusky, 2011). 
Seafloor spreading in the southern Red Sea began at $5 \mathrm{Ma}$. Spreading has propagated northward to $\sim 20^{\circ} \mathrm{N}$, but has not yet reached the latitude of Harrat Lunayyir $\left(25^{\circ} \mathrm{N}\right)($ Bosworth et al., 2015).

Camp and Roobol (1992) report two distinct phases of volcanism within the Arabian plate. From 30-20 Ma tholeiitic-to-transitional lavas were emplaced along rift-parallel dikes extending the entire length of the Red Sea rift flank, contemporaneous with the impingement of the Afar plume on the base of the African-Arabian plate. From $12 \mathrm{Ma}$ to the present, transitional-to-strongly-alkalic lavas have been emplaced along a N-S trend known as the Makkah-Madinah-Nafud (MMN) line of volcanism forming the younger harrats (Fig. 1) (Camp \& Roobol, 1992; Stern \& Johnson, 2010). Two stages of rifting and volcanism are also potentially reflected within the uplift history of the Arabian rift flank, with early uplift of a broad region of the Arabian-Nubian Shield progressively focusing to a narrow region around the Red Sea rift (Szymanski et al., 2016).

Mooney et al. (1985) analyzed seismic wide-angle reflection/refraction travel-times along a line through heat-flow measurement points 1, 2, 3 (Fig. 1) to the Red Sea and constrained the Arabian Shield upper-crustal P-wave velocity of $6.3 \mathrm{~km} / \mathrm{s}$ and mid-to-lower crustal velocities of $6.5-6.7 \mathrm{~km} / \mathrm{s}$, with the Moho $40 \mathrm{~km}$ depth. Not far below the Moho, both body-wave (e.g. Koulakov et al., 2016) and Rayleigh-wave (e.g. Yao et al., 2017) tomography show a strong decrease in S-wave velocity along the entire western margin of the Arabian craton, below $\sim 60 \mathrm{~km}$ beneath Harrat Lunayyir and gradually deepening toward the plate interior. Comparison with Swave receiver function converters (Hansen et al., 2007; Fig. 1) suggests this S-wave velocity decrease marks the lithosphere-asthenosphere boundary (LAB).

Measured heat flow within the Arabian Shield is 'cratonic' at $\sim 34 \mathrm{~mW} / \mathrm{m}^{2}$ despite the proximity of the Red Sea rift and spreading center, implying temperatures of $\sim 450-600^{\circ} \mathrm{C}$ at $40-50 \mathrm{~km}$ depth (Gosnold, 2011). However, geothermometry on xenoliths from Harrat Kishb (Fig. 1), on the eastern flank of the MMN line, suggests temperatures of $\sim 900-1000^{\circ} \mathrm{C}$ within this same depth range (McGuire \& Bohannon, 1989). A single heat-flow measurement located near Harrat Lunayyir (\#4, Fig. 1) is slightly elevated at $50 \pm 4 \mathrm{~mW} / \mathrm{m}^{2}$, implying temperatures of $800-1000^{\circ} \mathrm{C}$ at $40-50 \mathrm{~km}$ depth (Gosnold, 2011).

Volcanism within Harrat Lunayyir began at $\sim 600$ ka sourced by melt segregation within the asthenosphere at $\sim 60-75 \mathrm{~km}$ depth, and since then eruption rates have decreased and depth of melt segregation may have decreased (Duncan \& Al-Amri, 2013). Harrat Lunayyir last erupted during the $10^{\text {th }}$ century C.E. In 2009, a roughly N-S striking dike (Fig. 2) of $\sim 0.13 \mathrm{~km}^{3}$ reached within $1-2 \mathrm{~km}$ of the surface, and the associated $>30,000$ earthquakes, all with $\mathrm{m}_{\mathrm{b}} \leq 5.7$, caused evacuation of the nearby town of Al-Ays (Pallister et al., 2010). This volcano-tectonic crisis led to densification of the existing seismometer array from three sites before 2009 to 18 sites by August 2010, which provide the data for our study.

\section{Data and Methods}

\section{P-Wave Receiver Functions}

The Harrat Lunayyir seismic array now consists of 18 Trillium 120 broadband stations (Table 1) and spans a region $\sim 50 \times 50 \mathrm{~km}$ (Fig. 2). We used data from this array to create P-wave receiver functions (PRFs) from 857 earthquakes recorded during 2008-2015 with epicentral distances of 30-90 , largely from backazimuths of $020-120^{\circ}$ and with moment magnitudes of 5.5-8.3 (Fig. 3).

P-wave receiver functions (Langston, 1979) are created for each station using teleseismic events recorded from 2009-2014. The three-component seismograms were first rotated to the Radial-TransverseVertical (RTZ) coordinate system to isolate the first arrival on the vertical component and the P- to S-wave conversion on the radial component. Arrival times for every station-event pair were initially picked using a short-term average (STA) over long-term average (LTA) algorithm based on the method of Earle and Shearer (1994). These initial arrival times were then manually refined to correct for picking errors, as well as visually inspected to ensure that data with no clear arrivals were excluded from the analysis.

To calculate each receiver function we took $100 \mathrm{~s}$ of seismic data, filtered from 0.2 to $1.5 \mathrm{~Hz}$. The traces begin $20 \mathrm{~s}$ before the first P-wave arrival and include $80 \mathrm{~s}$ of post-arrival data. The receiver functions were constructed by deconvolving the vertical $(Z)$ signal from the radial $(R)$ trace using the iterative-time domain approach of Ligorria and Ammon (1999) as implemented in the codes of Hermann (2013). Receiver 
functions were visually evaluated for consistency by comparing each event at a station to all other events at the same station. We then performed common conversion-point stacking of the receiver functions in order to gain a better estimate of the three-dimensional structure of the lithosphere using the FuncLab program (Eager \& Fouch, 2012). Each stack was bootstrap-resampled by $150 \%$ and a minimum threshold value for plotting each voxel was set equal to the standard deviation of the stack at each voxel.

Table 1. Locations of Harrat Lunayyir seismic stations

\begin{tabular}{cccccc}
\hline Sensor & Station & $\begin{array}{c}\text { Latitude } \\
\left({ }^{\circ} \mathbf{N}\right)\end{array}$ & $\begin{array}{c}\text { Longitude } \\
\left({ }^{\circ} \mathbf{E}\right)\end{array}$ & $\begin{array}{c}\text { Elevation } \\
(\mathbf{m})\end{array}$ & $\begin{array}{c}\text { Operational } \\
\text { Date } \\
\text { MM/DD/YY) }\end{array}$ \\
\hline & & & & & \\
\hline T120 & LNY01 & 25.2200 & 37.9600 & 828 & $05 / 12 / 09$ \\
T120 & LNY02 & 25.1378 & 37.8610 & 1143 & $05 / 13 / 09$ \\
T120 & LNY03 & 25.3799 & 37.8543 & 631 & $05 / 14 / 09$ \\
T120 & LNY04 & 25.2716 & 37.6450 & 508 & $05 / 12 / 09$ \\
T120 & LNY05 & 25.0460 & 37.6953 & 620 & $06 / 05 / 09$ \\
T120 & LNY06 & 25.2098 & 37.7781 & 1044 & $05 / 31 / 09$ \\
T120 & LNY07 & 25.1296 & 37.5699 & 406 & $11 / 19 / 09$ \\
T120 & LNY08 & 25.0330 & 37.8500 & 1205 & $07 / 26 / 10$ \\
T120 & LNY09 & 25.4012 & 37.6614 & 650 & $07 / 26 / 10$ \\
T120 & LNY10 & 25.2700 & 37.8620 & 907 & $07 / 25 / 10$ \\
T120 & LNY11 & 25.3170 & 37.7728 & 1015 & $07 / 25 / 10$ \\
T120 & LNY12 & 25.2715 & 37.7717 & 995 & $07 / 25 / 10$ \\
T120 & LNY13 & 25.1724 & 37.6332 & 524 & $03 / 19 / 12$ \\
T120 & LNY14 & 25.2536 & 37.7661 & 1007 & $03 / 20 / 12$ \\
T120 & LNY15 & 25.2600 & 37.7960 & 1002 & $03 / 20 / 12$ \\
T120 & LNY16 & 25.3510 & 37.5980 & 489 & $12 / 11 / 11$ \\
T120 & LNY17 & 25.2422 & 37.8028 & 1000 & $04 / 23 / 12$ \\
T120 & LNYS & 25.0815 & 37.9439 & 1029 & $05 / 01 / 09$ \\
T40 & UMJS & 25.2323 & 37.3109 & 250 & $01 / 01 / 09$ \\
T120 & SUMJS & 24.7572 & 37.3997 & 198 & $12 / 09 / 11$ \\
T120 & TRAS & 25.0596 & 38.5670 & 337 & $03 / 18 / 12$ \\
\hline & & & & & \\
\hline
\end{tabular}

Our common conversion-point "cube" (Fig. 3) shows a clear, coherent and continuous positive polarity discontinuity (i.e., an upward decrease in seismic impedance for the P-to-S conversion) at $38 \mathrm{~km}$ below the surface. The average half-width of the pulse at half-maximum amplitude provides our uncertainty estimate of \pm $2 \mathrm{~km}$. This positive polarity (Fig. 3) represents the Moho, in agreement with previous crustal thickness estimates (Hansen et al., 2007; Park et al., 2008; Mechie et al., 2013; Tang et al., 2016). At $60 \mathrm{~km}$ we observe a seismic converter with opposite polarity to that of the Moho (Fig. 3) that we interpret as the lithosphereasthenosphere boundary (LAB), also consistent with previous lower-resolution estimates (Hansen et al., 2007; Park et al., 2008; Koulakov et al., 2016). The average half-width at half-maximum of the LAB signal is also 2 $\mathrm{km}$, but due to its less-focused appearance we use a more conservative uncertainty estimate of $\pm 5 \mathrm{~km}$. It is uncommon to image the LAB using P-wave receiver functions due to the interference of crustal multiples (Kind et al., 2012), but here we benefit from dense station coverage, numerous teleseismic events, and a mantle-lid that is significantly thinner than the crust. In stark contrast to the $60-\mathrm{km}$ thickness beneath Harrat Lunayyir, a lithospheric thickness of $100-150 \mathrm{~km}$ is reported at the transition from the shield to the platform beneath central Saudi Arabia (Hansen et al., 2007) and even thicker lithosphere ( $\geq 200 \mathrm{~km}$ ) beneath the eastern Arabian Peninsula (Koulakov et al., 2016). 
a

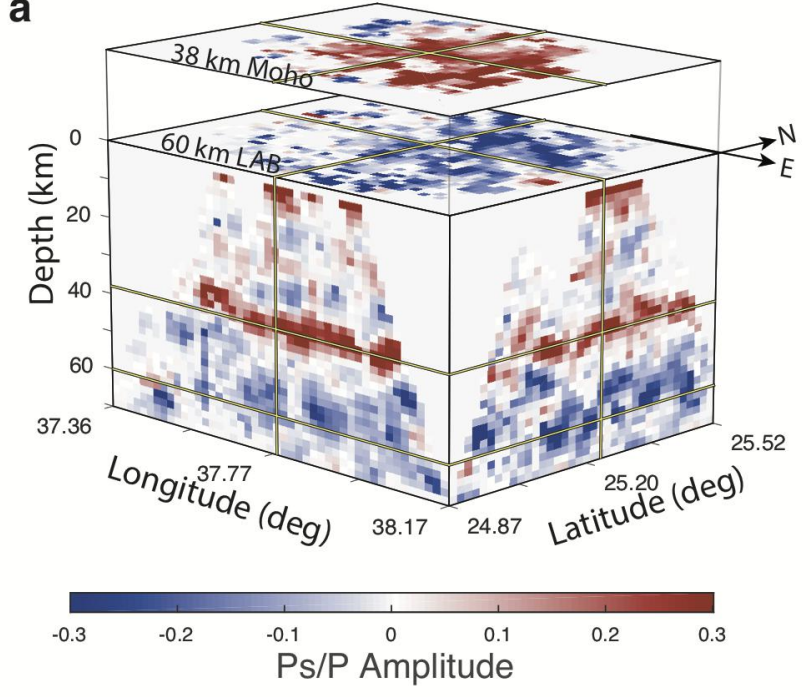

b

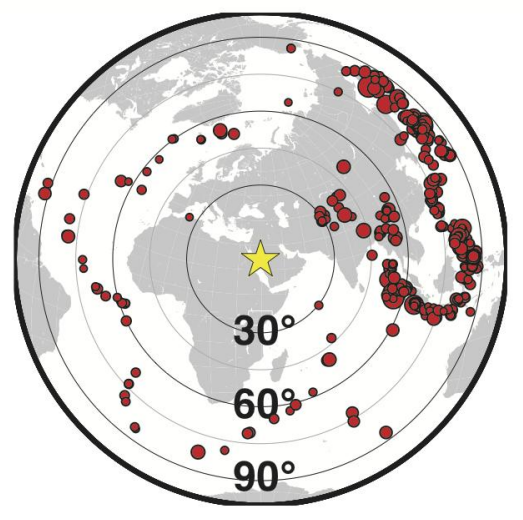

Figure 3. a) Horizontal and vertical slices through our three-dimensional common conversion point stack of P-wave receiver functions. Yellow lines mark the locations of slices through the cube that are displayed on the different faces. The top-most slice is a constant depth slice through the Moho at $38 \mathrm{~km}$ depth. The slice on the top face of the cube is a constant depth slice through the LAB at $60 \mathrm{~km}$ depth. The left and right faces of the cube are constant latitude and longitudes slices, respectively. Voxels are $2 \mathrm{~km}$ on each size. Areal extent of the cube is shown in Figure 2. The color-scale represents the amplitude of stacked conversions (P- to S-waves) with respect to the incident $\mathrm{P}$-waves. Negative amplitudes (blue) indicate a wave-speed decrease with depth and positive amplitudes (red) indicate a wave-speed increase with depth. b) The azimuthal distribution of teleseismic events used to generate Pwave receiver functions. The gold star is centered on the study area.

\section{Earthquake Spatio-temporal Patterns}

The Saudi Geological Survey (SGS) provided an event-catalog for 2009-2014 (Fig. 4) and continuous digital seismic data for the entire calendar year 2014. The 2014 event-catalog contains 72 earthquakes with unusual source depths of 40-50 km beneath Harrat Lunayyir and with local magnitudes of 0.2-2.5 (Fig. 5). We re-located the mantle earthquakes using hypoinverse (Klein, 2002) to improve absolute locations and HypoDD (Waldhauser, 2001) to reduce relative errors between events, using the IASP91 velocity model (Table 2; Kennett, 1991). Our relocations confirm that 64 of these catalog events are indeed below the 38-km deep Moho, all at depths of 42-48 km and all located $\sim 30 \mathrm{~km}$ southeast of the 2009 dike (Fig. $2 \&$ 5; Table 3). Reported relative depth uncertainties from HypoDD (Waldhauser, 2001), using the SVD method, are $\pm 100 \mathrm{~m}$. Absolute uncertainties depend on array geometry. Our preferred earthquake depths minimize the observed S- minus Pwave travel-time residuals with a median RMS error of $<0.23$ s (Fig. $6 \&$ 7) across all 64 sub-Moho events. Because there exists only one station east of these earthquakes (TRAS, Fig. 6 \& 7), we calculate the RMS of Sminus-P residuals (i.e., observed-minus-calculated travel-times) from all stations for each event, on a 1-km grid across a $1000 \mathrm{~km}^{2} \mathrm{~N}-\mathrm{S}$ swath encompassing the hypocenters and at depths every $0.33 \mathrm{~km}$ from the surface to $\sim 70 \mathrm{~km}$ (i.e. 210,000 trial locations) (Fig. 6) and across a W-E swath (Fig. 7). A histogram of the number of source locations yielding a given RMS S-minus-P residual, plotted against the difference in depth between the tested source location and our preferred depth (Fig. $6 \&$ 7), shows a narrow minimum in the distribution of residuals, indicating that our better constrained earthquakes have depth uncertainties $<5 \mathrm{~km}$. Hence, we confirm that all 64 events are likely in the mantle. 


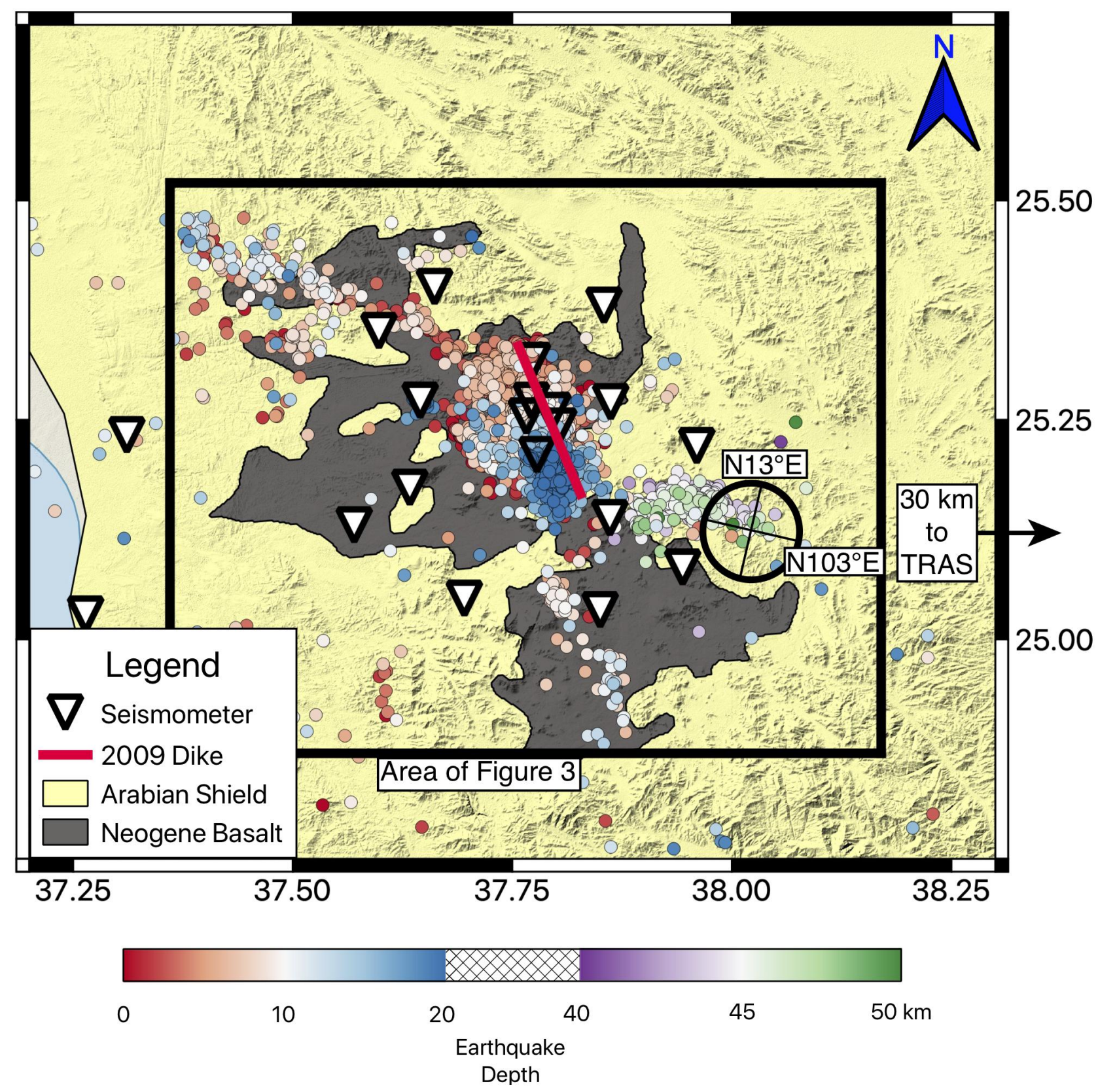

Figure 4. Map of the Harrat Lunayyir volcanic field as in Figure 2, except events plotted here are the 20092013 catalog locations. Mantle earthquakes are located slightly more to the west and cover a broader geographic area compared to our relocated events from the 2014 data (Fig. 2). None of these events have been relocated. 


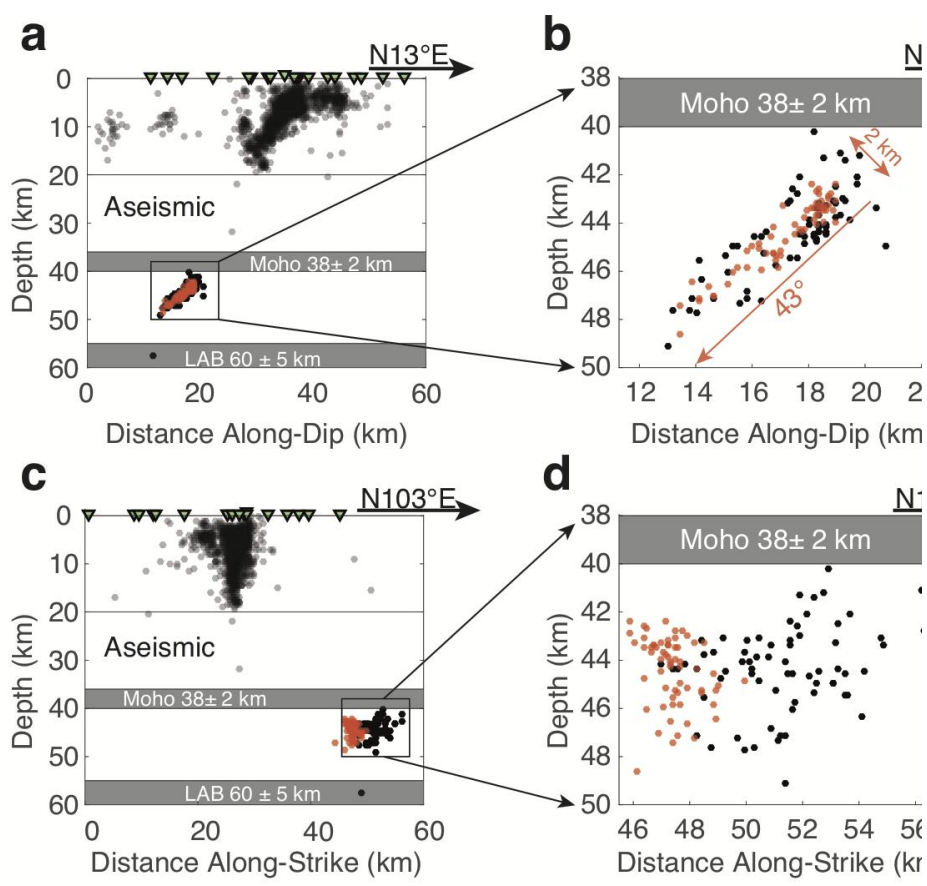

Figure 5. Comparison of catalog locations and relocated mantle earthquakes. Earthquakes above the Moho are semi-transparent gray dots. Original mantle earthquake locations are black dots and our new locations are red dots. Directions of plots are labeled at the top and shown in figure 2. a) Crosssectional view of earthquake hypocenters along dip direction of the cluster. b) Enlargement to show the differences between the original locations and our new relocations. c) Plot of hypocenters along strike direction of the cluster. d) Enlargement to show the differences in the original locations versus our relocations.

Table 2. SGS Velocity Model for Original Earthquake Locations compared to IASP91 Velocity Model used for Relocations

\begin{tabular}{|c|c|c|c|}
\hline \multicolumn{2}{|c|}{ SGS velocity model } & \multicolumn{2}{|c|}{ IASP91 velocity model } \\
\hline $\begin{array}{c}\mathbf{V p} \\
(\mathbf{k m} / \mathbf{s})\end{array}$ & $\begin{array}{c}\text { Top of Layer } \\
(\mathbf{k m})\end{array}$ & $V p(\mathbf{k m} / \mathbf{s})$ & $\begin{array}{c}\text { Top of Layer } \\
(\mathbf{k m})\end{array}$ \\
\hline 3.3 & 0.0 & 5.8 & 0.0 \\
\hline 5.0 & 1.0 & 6.5 & 20.0 \\
\hline 5.7 & 4.0 & 8.0 & 35.0 \\
\hline 6.7 & 15.0 & & \\
\hline 8.0 & 25.0 & & \\
\hline
\end{tabular}

Table 3. Hypocentral parameters for re-located sub-Moho earthquakes (magnitude from catalog)

\begin{tabular}{|c|c|c|c|c|c|c|c|}
\hline $\begin{array}{c}\text { Date } \\
\text { (YYYY-MM- } \\
\text { DD) } \\
\end{array}$ & $\begin{array}{c}\text { Origin } \\
\text { Time } \\
(\text { HHmm) }\end{array}$ & $\begin{array}{c}\begin{array}{c}\text { Origin } \\
\text { Time } \\
\text { (seconds) }\end{array} \\
\end{array}$ & $\begin{array}{c}\text { Latitude } \\
\left({ }^{\circ}\right)\end{array}$ & $\begin{array}{c}\text { Longitude } \\
\left({ }^{\circ}\right)\end{array}$ & $\begin{array}{c}\text { Depth } \\
(\mathbf{k m})\end{array}$ & $\begin{array}{c}\text { Magnitude } \\
\left(\mathbf{M}_{\mathrm{L}}\right)\end{array}$ & $\begin{array}{l}\begin{array}{c}\text { Number } \\
\text { of } \\
\text { Stations }\end{array} \\
\end{array}$ \\
\hline $2014-1-13$ & 1608 & 0.67 & 25.12 & 38.00 & 45.9 & 1.09 & 17 \\
\hline 2014-1-13 & 1647 & 0.76 & 25.12 & 38.01 & 45.3 & 0.92 & 17 \\
\hline 2014-1-13 & 1713 & 0.20 & 25.11 & 38.01 & 45.2 & 0.72 & 14 \\
\hline 2014-1-21 & 0014 & 0.60 & 25.12 & 38.01 & 44.2 & 0.64 & 11 \\
\hline 2014-1-21 & 1403 & 0.36 & 25.12 & 38.01 & 45.3 & 0.65 & 7 \\
\hline $2014-1-22$ & 0155 & 0.54 & 25.12 & 38.01 & 45.9 & 1.06 & 16 \\
\hline $2014-1-26$ & 1847 & 0.24 & 25.12 & 38.00 & 44.8 & 0.81 & 10 \\
\hline $2014-1-26$ & 1929 & 0.40 & 25.13 & 38.01 & 44.4 & 0.94 & 9 \\
\hline $2014-2-8$ & 0833 & 0.95 & 25.12 & 38.01 & 45.5 & 1.22 & 12 \\
\hline 2014-3-1 & 2156 & 59.96 & 25.13 & 38.01 & 45.3 & 0.67 & 8 \\
\hline 2014-3-4 & 2232 & 0.54 & 25.12 & 38.01 & 45.3 & 0.69 & 8 \\
\hline $2014-3-4$ & 2338 & 59.96 & 25.13 & 38.01 & 45.2 & 0.92 & 10 \\
\hline 2014-3-12 & 1955 & 0.24 & 25.13 & 38.01 & 44.1 & 0.89 & 5 \\
\hline
\end{tabular}




\begin{tabular}{|c|c|c|c|c|c|c|c|}
\hline $2014-3-12$ & 1957 & 1.00 & 25.13 & 38.01 & 44.2 & 0.7 & 4 \\
\hline $2014-4-2$ & 1716 & 0.72 & 25.12 & 38.02 & 45.0 & 1.3 & 11 \\
\hline $2014-4-2$ & 1717 & 0.44 & 25.12 & 38.02 & 45.3 & 1.46 & 9 \\
\hline $2014-4-7$ & 0008 & 0.11 & 25.12 & 38.02 & 44.6 & 0.79 & 10 \\
\hline 2014-4-10 & 0150 & 0.00 & 25.12 & 38.01 & 44.9 & 1.43 & 17 \\
\hline $2014-4-26$ & 1622 & 0.71 & 25.13 & 38.00 & 43.6 & 1.18 & 17 \\
\hline 2014-4-26 & 2100 & 0.64 & 25.13 & 38.00 & 43.7 & 0.91 & 13 \\
\hline $2014-4-26$ & 2210 & 0.28 & 25.13 & 37.99 & 43.4 & 1.16 & 14 \\
\hline 2014-4-27 & 1742 & 0.24 & 25.13 & 38.00 & 43.4 & 0.64 & 12 \\
\hline $2014-5-3$ & 0742 & 1.02 & 25.13 & 38.00 & 43.4 & 1.49 & 8 \\
\hline $2014-5-3$ & 1035 & 0.92 & 25.13 & 38.00 & 43.5 & 0.82 & 9 \\
\hline $2014-5-3$ & 1215 & 0.13 & 25.14 & 38.00 & 44.0 & 0.77 & 12 \\
\hline $2014-5-3$ & 1345 & 0.08 & 25.13 & 38.00 & 43.8 & 1.08 & 9 \\
\hline $2014-5-3$ & 1558 & 0.68 & 25.13 & 38.00 & 43.8 & 0.93 & 10 \\
\hline $2014-5-3$ & 1921 & 0.30 & 25.14 & 38.01 & 43.0 & 0.9 & 11 \\
\hline $2014-5-3$ & 1954 & 0.32 & 25.13 & 38.00 & 43.4 & 0.94 & 15 \\
\hline $2014-5-4$ & 0038 & 59.98 & 25.14 & 38.00 & 43.4 & 0.63 & 10 \\
\hline $2014-5-4$ & 1352 & 0.90 & 25.14 & 38.01 & 43.3 & 0.65 & 7 \\
\hline $2014-5-4$ & 1521 & 0.44 & 25.13 & 38.00 & 43.2 & 0.9 & 10 \\
\hline $2014-5-5$ & 2318 & 0.40 & 25.13 & 38.00 & 43.3 & 0.66 & 13 \\
\hline $2014-5-6$ & 1702 & 0.04 & 25.13 & 38.00 & 44.2 & 0.84 & 12 \\
\hline $2014-5-6$ & 1814 & 0.88 & 25.13 & 38.00 & 44.0 & 0.75 & 10 \\
\hline $2014-5-7$ & 0105 & 0.93 & 25.14 & 38.00 & 44.0 & 0.95 & 17 \\
\hline $2014-5-7$ & 0247 & 0.24 & 25.14 & 38.01 & 43.3 & 0.64 & 13 \\
\hline $2014-5-7$ & 0716 & 0.65 & 25.13 & 38.00 & 44.4 & 1.03 & 11 \\
\hline $2014-5-7$ & 1855 & 0.80 & 25.14 & 38.00 & 43.0 & 0.9 & 16 \\
\hline $2014-5-7$ & 2101 & 59.92 & 25.12 & 37.99 & 43.3 & 1.01 & 14 \\
\hline $2014-5-7$ & 2110 & 0.96 & 25.14 & 38.00 & 42.8 & 0.61 & 6 \\
\hline $2014-5-7$ & 2117 & 0.84 & 25.13 & 37.99 & 42.4 & 0.7 & 9 \\
\hline $2014-5-7$ & 2129 & 0.04 & 25.13 & 38.00 & 43.4 & 0.75 & 7 \\
\hline $2014-5-7$ & 2146 & 0.70 & 25.13 & 37.99 & 42.6 & 0.99 & 10 \\
\hline $2014-5-8$ & 1733 & 0.12 & 25.14 & 38.00 & 42.7 & 0.85 & 5 \\
\hline $2014-5-8$ & 1804 & 0.48 & 25.14 & 37.99 & 42.9 & 0.61 & 4 \\
\hline $2014-5-8$ & 1919 & 0.60 & 25.14 & 38.00 & 42.4 & 0.77 & 8 \\
\hline $2014-5-8$ & 2114 & 0.08 & 25.14 & 37.99 & 43.0 & 0.65 & 7 \\
\hline $2014-5-8$ & 2146 & 0.08 & 25.13 & 37.99 & 42.6 & 0.64 & 10 \\
\hline $2014-5-9$ & 1356 & 0.19 & 25.13 & 37.99 & 43.5 & 0.94 & 9 \\
\hline $2014-5-11$ & 0324 & 0.28 & 25.14 & 38.00 & 43.4 & 0.75 & 17 \\
\hline $2014-6-15$ & 1604 & 0.42 & 25.10 & 38.01 & 47.0 & 1.02 & 15 \\
\hline 2014-6-19 & 2335 & 0.56 & 25.11 & 38.00 & 46.0 & 0.22 & 11 \\
\hline $2014-6-20$ & 0132 & 0.78 & 25.11 & 38.01 & 46.5 & 0.79 & 15 \\
\hline $2014-6-24$ & 0459 & 0.76 & 25.11 & 38.01 & 45.9 & 0.51 & 9 \\
\hline $2014-7-4$ & 0156 & 0.95 & 25.12 & 38.03 & 44.9 & 0.23 & 14 \\
\hline $2014-7-6$ & 1130 & 0.52 & 25.12 & 38.02 & 45.8 & 0.31 & 9 \\
\hline
\end{tabular}




\begin{tabular}{cccccccc}
\hline $2014-7-31$ & 2019 & 0.16 & 25.10 & 38.02 & 46.4 & 0.69 & 10 \\
$2014-8-3$ & 0104 & 0.18 & 25.10 & 38.01 & 46.7 & 0.69 & 16 \\
$2014-8-15$ & 1721 & 59.96 & 25.10 & 37.98 & 47.0 & 0.67 & 4 \\
$2014-8-19$ & 2153 & 0.80 & 25.09 & 38.01 & 47.5 & 2.45 & 20 \\
$2014-8-19$ & 2342 & 1.00 & 25.10 & 38.01 & 47.2 & 1.61 & 20 \\
$2014-8-28$ & 0046 & 0.20 & 25.10 & 38.01 & 47.2 & 2.14 & 20 \\
$2014-10-29$ & 0756 & 0.44 & 25.09 & 38.00 & 48.6 & 1.63 & 20 \\
\hline
\end{tabular}

We employ one final test to demonstrate that the earthquakes are indeed within the mantle lithosphere. The ability to accurately resolve the hypocentral location of an earthquake is strongly affected by the chosen velocity model, with incorrect models providing spurious results. Schulte-Pelkum et al. (2019) developed an elegant solution to this problem: comparing travel-time differences between S- and P-wave arrivals from local earthquakes with the equivalent travel-time difference from P-wave receiver functions at a nearby station, with both travel-time differences converted to vertical incidence. We used the station closest to the mantle earthquakes (LNYS, Fig. 2 and Table 1) as it is only $\sim 7.5 \mathrm{~km} \mathrm{SW}$ of the centroid of the mantle earthquakes. The comparison between PRFs and earthquake travel time differences in shown in figure 8. The energy from Pto-S converted waves at the Moho interface arrives at $\sim 4$ seconds, from the LAB at $\sim 5.9$ seconds, and the $\mathrm{S}$ minus P travel times for the mantle earthquakes span 5-5.5 seconds, clearly between the two interfaces. As noted by Schulte-Pelkum et al. (2019), the comparison between S minus P travel-time differences is rather insensitive to changes in velocity model so this technique clearly verifies our events are depper than the Moho. In figure 8 the mantle earthquakes are closer in S-minus-P time to the LAB than to the Moho, but this is an artifact due to the large change in wavespeed across the Moho. Figure 8 shows the relative, not the absolute depth of the mantle earthquakes. 

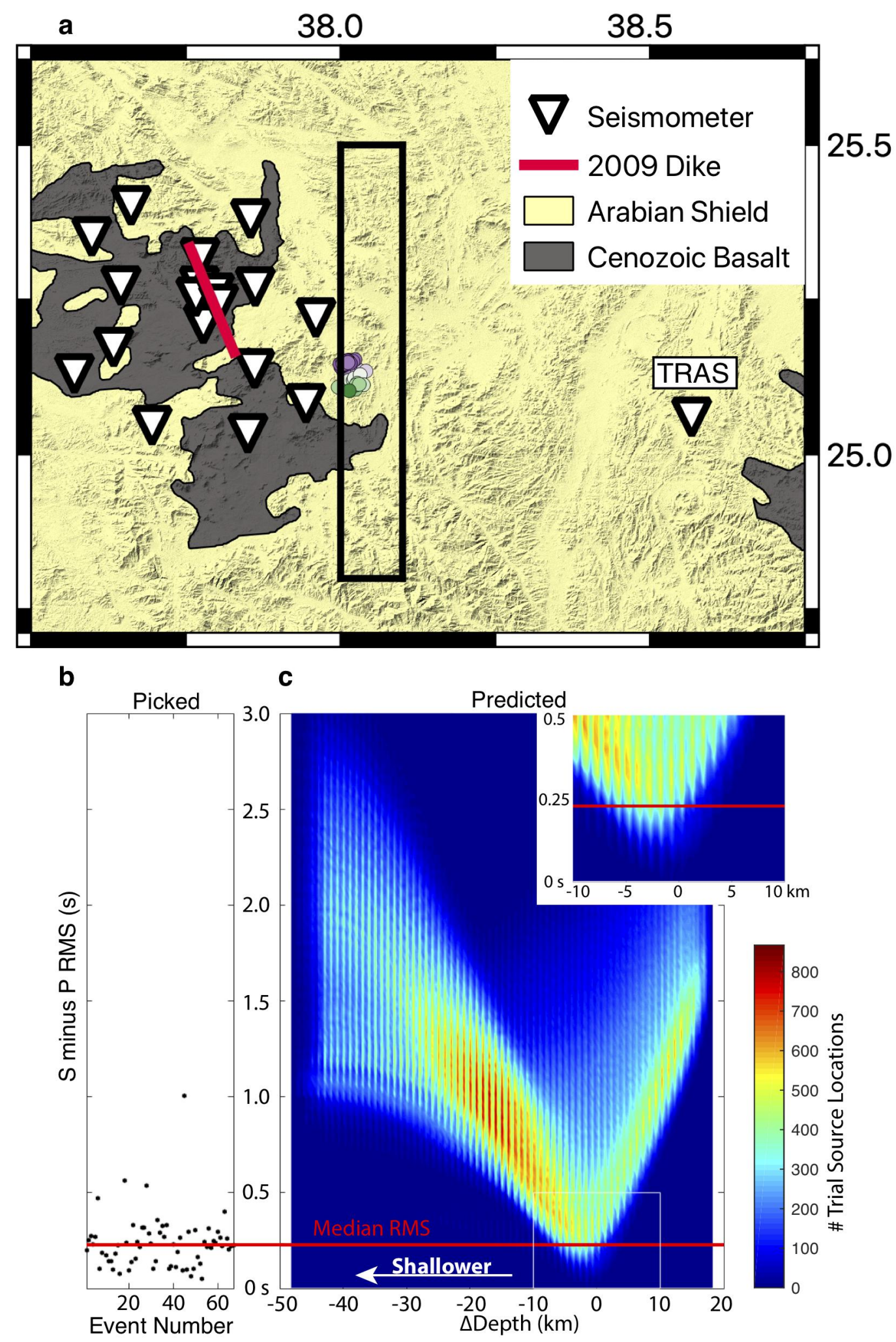

Figure 6. Test of absolute depth uncertainty. a) Map showing a portion of Harrat Lunayyir, the easternmost station (TRAS), and the mantle earthquake epicenters. Black box marks the bounds of the North-South grid search of S Minus P RMS residuals. b) Residuals for all events at the inverted locations. Red line at $0.23 \mathrm{~s}$ is the median of the residuals. c) Two-dimensional histogram of the number of occurrences of RMS S Minus P RMS residuals in $0.025 \mathrm{~s}$ bins at all possible $\Delta$ depths, in $0.33 \mathrm{~km}$ bins. The $\Delta$ depth inidicates the difference between the depth of each event location in our grid search and the preferred depth of the event, where a 
negative change in $\Delta$ depth indicates a test location shallower than the preferred location. The grid search was performed over a latitude range of $24.8-25.5^{\circ} \mathrm{N}$ and longitude range of $38.0-38.1^{\circ} \mathrm{E}$. The color-scale reflects a count of the number of residuals at a given change in depth across all events and test locations. The inset is a zoomed view of the minimum of the residuals.

a
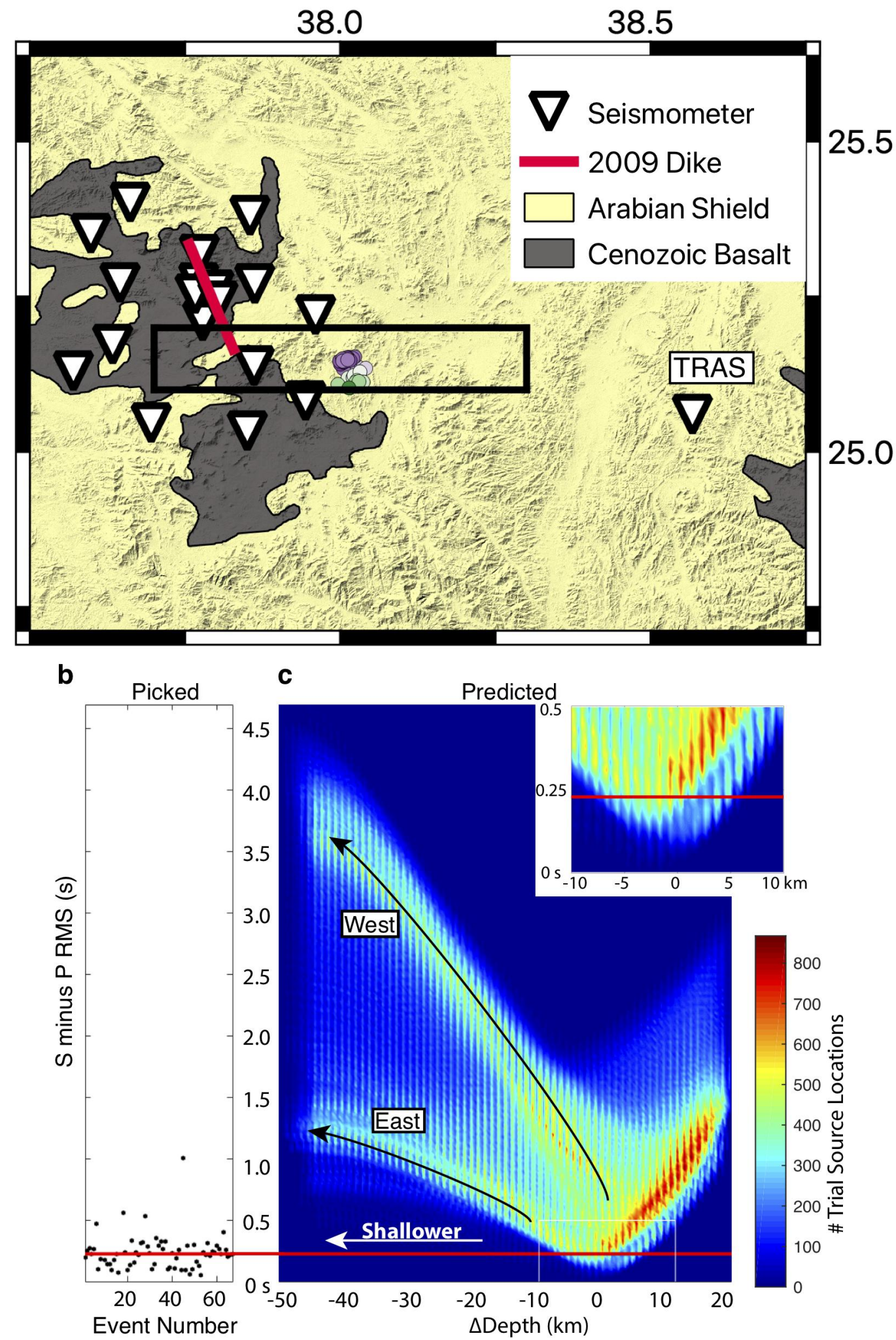

Figure 7. West-East grid search results. This figure complements Figure 6, which is a North-South grid search. a) Map showing a portion of Harrat Lunayyir, the easternmost station (TRAS), and the mantle earthquake 
epicenters. The black box marks the bounds of the East-West grid search of S Minus P RMS residuals. b) Residuals for all events at the inverted locations. Red line at $0.23 \mathrm{~s}$ is the median of the residuals. c) Twodimensional histogram of S Minus P RMS residuals versus change in depth. See caption for Figure 6 further details.

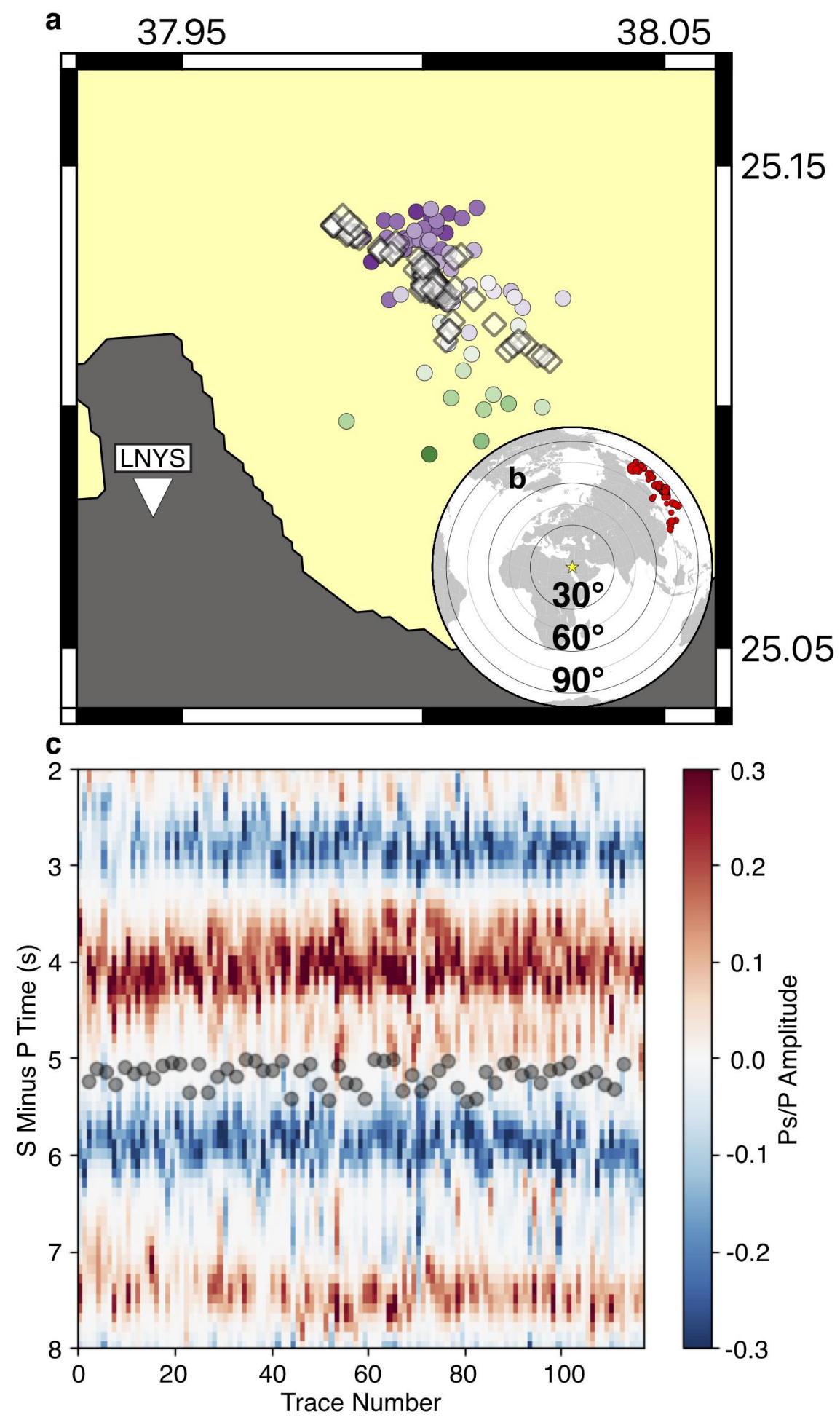

Figure 8. a) Map showing epicentral locations of mantle earthquakes (color-coded circles, same as in Fig. 2) and receiver function piercing points (transparent white diamonds) calculated at a depth of $40 \mathrm{~km}$ through the IASP91 reference velocity model. b) The azimuthal distribution of teleseismic events used to generate P-wave receiver functions, isolated to the same back-azimuth range as the mantle earthquakes to seismic station LNYS (117 in total). The gold star is centered on the study area. c) Comparison of vertical S minus $\mathrm{P}$ travel times 
from P-wave receiver functions (background) to mantle earthquakes (transparent gray circles, 59 in total), corrected to vertical incidence using a $\mathrm{Vp}=6.5 \mathrm{~km} / \mathrm{s}$ and assuming a Poisson solid.

Also during 2014, 6,000 earthquakes occurred at depths between $0-20 \mathrm{~km}$, with the vast majority of events spatially associated with the 2009 dike (Fig. 2 \& 5). There are three earthquakes in the 2014 SGS catalog with lower-crustal depths of 20-38 km. The waveforms for all three "lower-crustal" events have emergent/noisy first arrivals, making precise locations difficult to determine. We conclude that the lower-crust at $>20 \mathrm{~km}$ depth beneath Harrat Lunayyir was essentially aseismic in 2014.

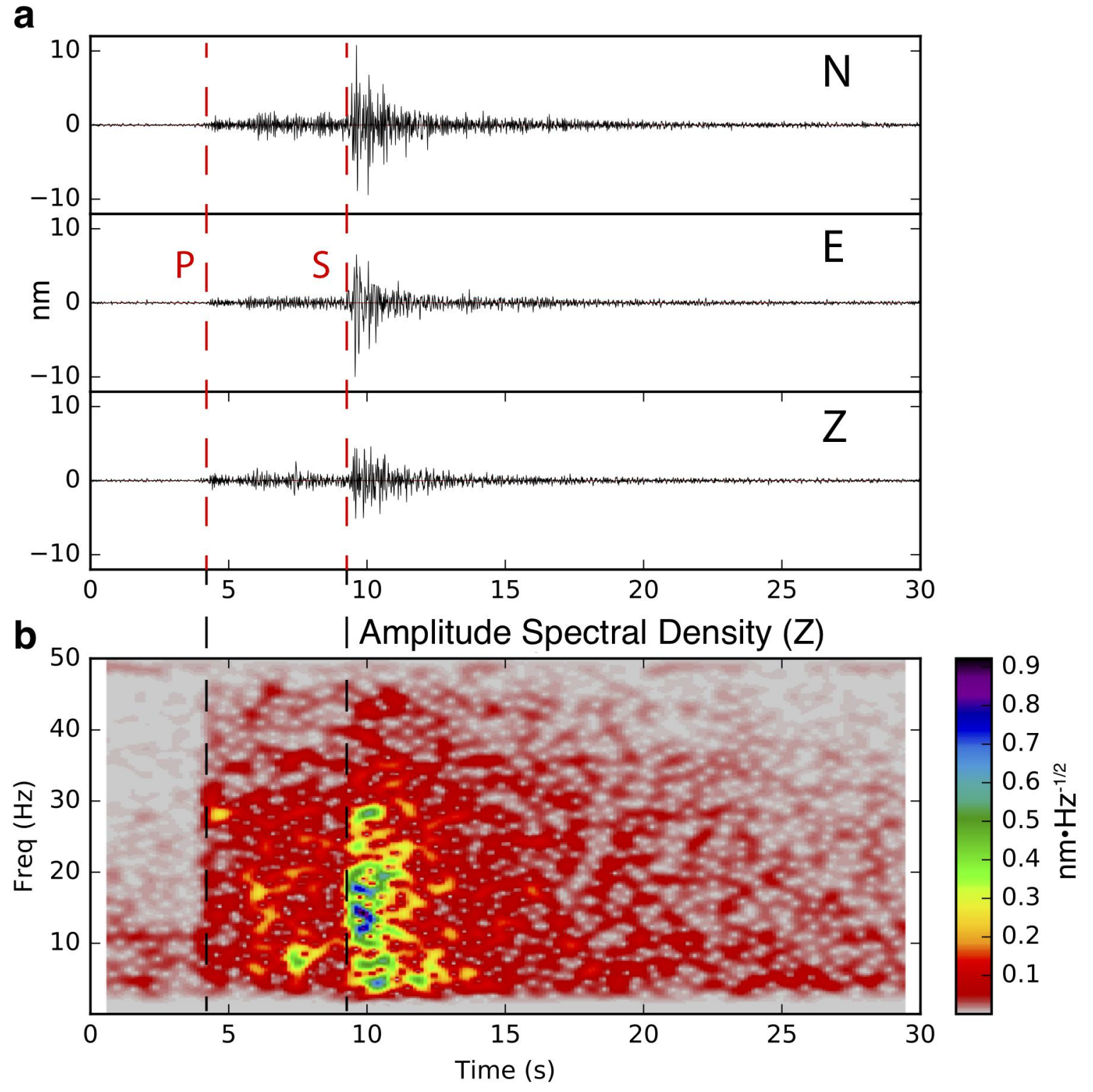

Figure 9. a) Three-component seismogram recorded by station LNY01, instrument response removed, of a $\mathrm{m}_{\mathrm{L}}$ $=1.1$ earthquake that has a source-depth of $45.4 \mathrm{~km}$, high-pass filtered above $1 \mathrm{~Hz}$. b) Spectrogram of the vertical $(Z)$ seismogram showing peak P-wave energy at $\sim 30 \mathrm{~Hz}$ and S-wave energy between 10-20 Hz. Nyquist frequency is $50 \mathrm{~Hz}$.

The mantle earthquakes beneath Harrat Lunayyir are dominated by high-frequency $(>5 \mathrm{~Hz})$ energy, with a peak at $\sim 30 \mathrm{~Hz}$ (Fig. 9). They have clear, impulsive P-and S-wave arrivals and match the characteristics of "brittle-failure" earthquakes (Hill \& Prejean, 2005). Brittle-failure earthquakes close to sites of active magmatism are commonly referred to as volcano-tectonic because they are indistinguishable from tectonic earthquakes despite occurring around volcanoes. Brittle-failure earthquakes contrast both with long-period (LP) 
volcano seismicity $(0.5-5 \mathrm{~Hz})$, caused by resonance within fluid-filled cracks, and with very long-period (VLP) seismicity $(0.01-0.5 \mathrm{~Hz}$ ), associated with the unsteady transport of magma and gases through conduits (Chouet \& Matoza, 2013). High-frequency, LP and VLP crustal earthquakes all occurred during the 2009 diking episode (Pallister et al., 2010), but none of the 2014 mantle earthquakes we examined have LP or VLP characteristics.

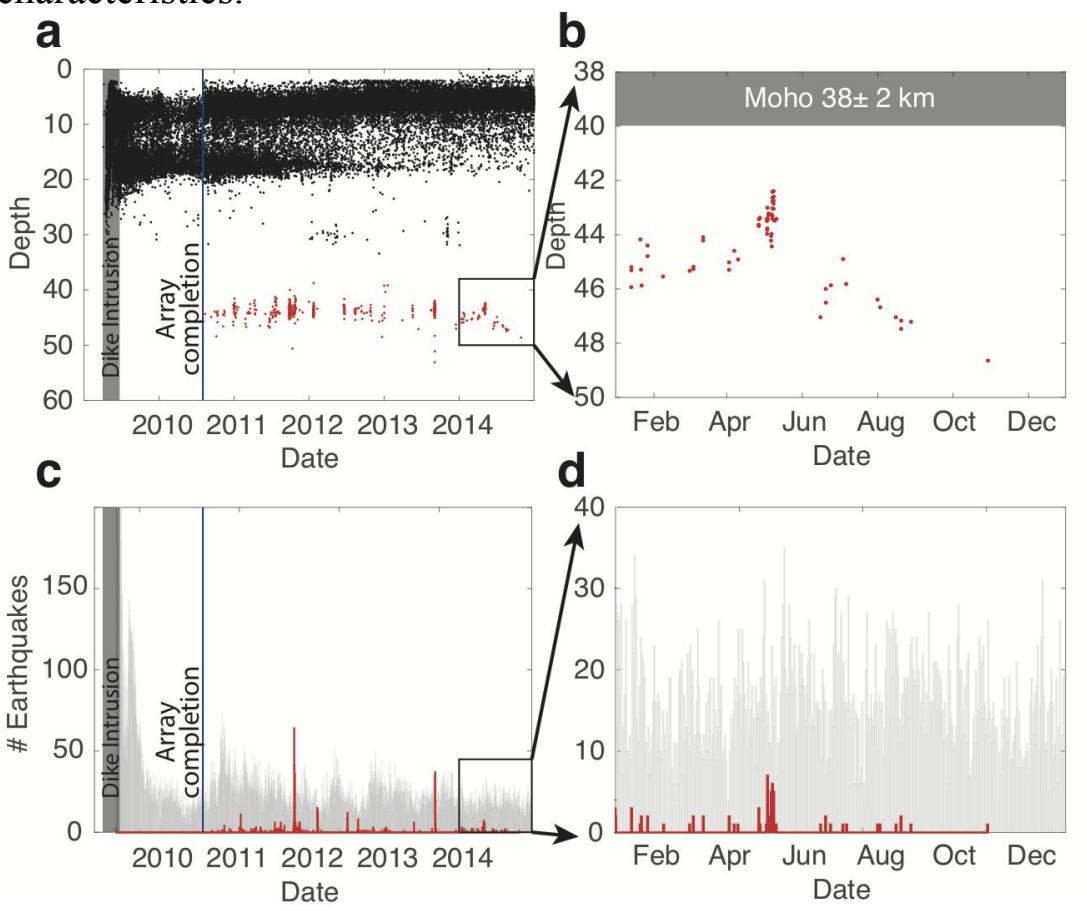

Figure 10. Temporal evolution of Harrat Lunayyir seismicity. a) Earthquake catalog hypocentral depths from April 19, 2009 through the end of 2014. b) Enlarged view of the relocated mantle earthquakes from 2014. c) Histogram of earthquakes over time. Gray histograms denote earthquakes with depths $<$ $36 \mathrm{~km}$, while red histograms denote earthquakes with depths $\geq 40 \mathrm{~km}$. d) sEnlarged view of earthquakes from 2014.

The 2014 Harrat Lunayyir earthquakes within the mantle lithosphere follow a three-part temporal evolution (Fig. $10 \mathrm{~b} \& \mathrm{~d}$ ) along a plane striking $\sim \mathrm{N} 103^{\circ} \mathrm{E}$ and dipping $\sim 43^{\circ} \mathrm{S}$ (Fig. 5). First, between January and early May 2014, events with magnitudes between $0.5-1.5$ occurred at a mean depth of $\sim 45 \mathrm{~km}$. Then, during an eight-day window in May 2014, $\sim 50 \%$ of the total known earthquakes occurred, $0.6 \leq \mathrm{m}_{\mathrm{L}} \leq 1.5$, and quickly migrated to the shallowest observed depth of $\sim 42 \mathrm{~km}$. The subsequent month-long quiescence was broken in June 2014 when the deepest sequence began at $46 \mathrm{~km}$, increasing to $48 \mathrm{~km}$, and encompassing the entire magnitude range (0.2-2.5) of the 2014 mantle earthquakes.

This three-part temporal trend does not correlate with the upper-crustal seismicity (Fig. 9d), which is roughly constant throughout the entire year. The temporal evolution of the earthquake locations matches "stage 1 " volcano seismicity caused by magma-driven fracturing and pooling between the LAB and Moho (McCausland et al., 2017). Similar patterns of seismicity are present in the SGS catalog between August 2010 and the end of 2013 (Fig. 10a \& c), indicating that the 2014 sequence is not an isolated occurrence and that there are likely numerous pulses of magma intruding close to the base of the crust.

\section{Derivation of Finite Differences Thermal Modeling Scheme}

We used a one-dimensional finite-differences code to model the thermal evolution of the lithosphere as it is eroded from below, following Turcotte and Schubert (2002) and Recktenwald (2004). We start with the one-dimensional time-dependent heat-conduction equation (Turcotte \& Schubert, 2002, eqn. 4.68), with the inclusion of radiogenic heat production:

$$
\frac{\partial T}{\partial t}=K\left(\frac{\partial^{2} T}{\partial z^{2}}+\frac{A(z)}{k}\right)
$$

where $K=\frac{k}{\rho c}$ is the thermal diffusivity and $A(z)$ is the volumetric heat production of the medium (for parameter definitions see Table 4). If we assume that the concentration of heat-producing elements decays exponentially as a function of depth from the surface with a characteristic decay constant $\mathrm{h}_{\mathrm{r}}$, we can write the volumetric heat production as: 


$$
A(z)=A_{0} e^{-z / h_{r}}
$$

Substituting equation (2) into equation (1) we obtain:

$$
\frac{\partial T}{\partial t}=K \frac{\partial^{2} T}{\partial z^{2}}+B e^{-z / h_{r}}
$$

where $B=\frac{K A_{0}}{k}$ is a constant related to the medium. This is the one-dimensional heat-flow equation with internal heat production that we next solve using the centered-space finite-differences approximation for the term involving the second spatial derivative of the temperature:

$$
\left.\frac{\partial^{2} T}{\partial z^{2}}\right|_{z=z_{m}} \approx \frac{T_{m-1}-2 T_{m}+T_{m+1}}{\Delta z^{2}}
$$

where $m$ indicates the spatial node on a discrete mesh. Next, we use the forward-time finite-differences approximation for the left-hand side of equation (3):

$$
\left.\frac{\partial T}{\partial t}\right|_{t=t_{n}} \approx \frac{T^{n+1}-T^{n}}{\Delta t} \quad \#(5)
$$

where $\mathrm{n}$ indicates the temporal node on a discrete mesh. In equations (4) and (5), $\Delta \mathrm{z}$ and $\Delta \mathrm{t}$ are the distances between spatial and temporal nodes, respectively. Substituting equations (4) and (5) into equation (3) produces:

$$
\frac{T_{m}^{n+1}-T_{m}^{n}}{\Delta t}=K \frac{T_{m-1}^{n}-T_{m}^{n}+T_{m+1}^{n}}{\Delta z^{2}}+B e^{-z_{m} / h_{r}}
$$

where superscripts denote temporal nodes and subscripts are spatial nodes. Rearranging the terms to solve for the temperature at spatial node $m$ in the next time step, $n+1$, we get:

$$
T_{m}^{n+1}=T\left(z_{m}, t_{n+1}\right)=T_{m}^{n}+\frac{K \Delta t}{\Delta z^{2}}\left(T_{m-1}^{n}-T_{m}^{n}+T_{m+1}^{n}\right)+\Delta t B e^{-z_{m} / h_{r}} \quad \#(7)
$$

We simplify the equation by setting:

to obtain:

$$
r=\frac{K \Delta t}{\Delta z^{2}} ; s=1-2 r ; C=\Delta t B
$$

$$
T_{m}^{n+1}=r\left(T_{m+1}^{n}+T_{m-1}^{n}\right)+s T_{m}^{n}+C e^{-z_{m} / h_{r}}
$$

This is an explicit equation for the temperature at spatial node $m$ and time step $n+1$ only in terms of the previous time step. The constant $r$ is the stability parameter for the finite differences scheme. The solution is stable on the condition that $r \leq \frac{1}{2}$ (Recktenwald, 2004).

To obtain an input temperature profile, we use the solution for the steady-state heat-flow equation with internal heat generation (Turcotte \& Schubert, 2002, eqn. 4.30):

$$
T(z)=T_{0}+\frac{q_{m} z}{k}+\frac{A_{0} h_{r}^{2}}{k}\left(1-e^{-z / h_{r}}\right) \quad \#(9)
$$

To solve for $\mathrm{q}_{\mathrm{m}}$, the reduced heat flow, we apply the boundary condition at the surface $(\mathrm{z}=0)$ as shown in equations (10) and (11):

$$
\begin{gathered}
-q(z=0)=q_{0}=q_{m}+A_{0} h_{r} \quad \#(10) \\
q_{m}=q_{0}-A_{0} h_{r}
\end{gathered}
$$

In order to use equation (8) to solve equation (3), we need two boundary conditions: temperatures at the surface $\left(\mathrm{T}_{0}\right)$ and at the lithosphere-asthenosphere boundary ( $\mathrm{T}_{\mathrm{LAB}}$ at depth $\left.\mathrm{Z}_{\mathrm{LAB}}\right)$. The surface boundary condition is simply the average temperature at the surface $\left(25^{\circ} \mathrm{C}\right.$, Table 4$)$. Mantle temperature depends on the mantle potential temperature, $T_{p}$, and the adiabatic temperature gradient within the mantle:

$$
T=T_{p}+z \frac{d T}{d z} ; z \geq z_{L A B}
$$

Table 4. Thermal Model Parameters 


\begin{tabular}{|c|c|c|c|}
\hline Parameter & Description & Value [units] & Reference \\
\hline$A_{0}$ & $\begin{array}{c}\text { Near-surface volumetric } \\
\text { heat production }\end{array}$ & $1.04\left[\frac{\mu W}{m^{3}}\right]$ & Gettings (1982) \\
\hline$T_{0}$ & Temperature at surface & $25\left[{ }^{\circ} \mathrm{C}\right]$ & Almazroui (2012) \\
\hline$h_{r}$ & $\begin{array}{c}\text { Exponential decay } \\
\text { distance }\end{array}$ & $10[\mathrm{~km}]$ & Gettings (1982) \\
\hline$\Delta z$ & Node spacing in depth & $100[\mathrm{~m}]$ & \\
\hline$\Delta t$ & Node spacing in time & $100[\mathrm{yr}]$ & \\
\hline$T_{p}$ & $\begin{array}{c}\text { Mantle potential } \\
\text { temperature }\end{array}$ & $1354\left[{ }^{\circ} \mathrm{C}\right]$ & Camp and Roobol (1992) \\
\hline$\frac{d T}{d z}$ & Mantle adiabatic gradient & $0.3\left[\frac{{ }^{\circ} \mathrm{C}}{\mathrm{km}}\right]$ & Camp and Roobol (1992) \\
\hline$C$ & Specific heat & $1.13\left[\frac{k J}{k g^{\circ} \mathrm{C}}\right]$ & Gettings (1982) \\
\hline$\rho$ & Density & $3200\left[\frac{\mathrm{km}}{\mathrm{m}^{3}}\right]$ & Gettings (1982) \\
\hline$k_{\text {surface }}$ & $\begin{array}{l}\text { Near-surface thermal } \\
\text { conductivity }\end{array}$ & $3.51\left[\frac{W}{m^{\circ} C}\right]$ & Gettings (1982) \\
\hline$k_{\text {avg }}$ & $\begin{array}{c}\text { Average thermal } \\
\text { conductivity }\end{array}$ & $2.51\left[\frac{W}{m^{\circ} \mathrm{C}}\right]$ & Gettings (1982) \\
\hline$t_{\text {thin }}$ & $\begin{array}{c}\text { Duration of lithospheric } \\
\text { thinning prior to time } \\
\text { zero }\end{array}$ & 10 [Myr] & \\
\hline$t_{\text {total }}$ & Total model run & $35[\mathrm{Myr}]$ & \\
\hline$q_{0}$ & Initial surface heat-flow & $30\left[\frac{m W}{m^{2}}\right]$ & $\begin{array}{c}\text { Global Heat Flow } \\
\text { Database }\end{array}$ \\
\hline
\end{tabular}

We assume that the seismic lithosphere-asthenosphere boundary is coincident with the thermal definition of the lithosphere-asthenosphere boundary as the intersection between the conductive lithospheric thermal profile and the adiabatic mantle-asthenosphere thermal profile. If, as we show in this paper, the lithosphere is not in thermal equilibrium with the underlying asthenosphere due to geologically recent thermal erosion, then we would indeed expect a narrow seismic transition zone (seismic LAB) at the thermal lithosphere-asthenosphere boundary (Aulbach et al., 2017).

\section{Thermal Constraints}

The maximum depth at which intra-continental earthquakes nucleate is controlled by strain-rate, lithology and temperature (e.g. Chen \& Molnar, 1983). Reilinger and McClusky (2011) report that strain-rates within the Arabian Shield are below their detection threshold $\left(<10^{-15} \mathrm{~s}^{-1}\right)$. Due to our interest in the mantle lithosphere, we restrict our analysis to olivine-dominated lithologies. The clear cut-off in earthquakes at $48 \pm 2$ $\mathrm{km}$ depth below Harrat Lunayyir shows that at this depth the modern temperature is at the maximum at which brittle-failure earthquakes can occur, which must be $\leq 900-1000^{\circ} \mathrm{C}$ as measured from xenoliths at Harrat Kishb (McGuire \& Bohannon, 1989).

Chen \& Molnar (1983) suggest that crustal and mantle seismicity are limited to temperatures less than $\sim 350 \pm 100$ and $\sim 700 \pm 100^{\circ} \mathrm{C}$, respectively, thought to represent brittle-ductile transitions in the crust and upper mantle. More recently, a $600^{\circ} \mathrm{C}$ cut-off in seismicity in the mantle has been estimated for oceans (McKenzie et al., 2005) and continents (Sloan \& Jackson, 2012). However, in volcanic areas, due to elevated strain-rates, lower-crustal brittle-failure earthquakes are well known from regions thought to be hotter, 700$750^{\circ} \mathrm{C}$ (Shelly \& Hill 2011; White et al., 2011). Ágústsson \& Flóvenz (2005) used geothermal data to constrain the maximum nucleation depths of earthquakes beneath Iceland to temperatures of $600-900^{\circ} \mathrm{C}$. Although lithological considerations alone suggest mantle-lithosphere brittle-failure earthquakes should therefore be common in continental volcanic areas, they are only rarely reported. For example, there are no brittle-failure events beneath the Cascade volcanic arc where LP earthquakes are recognized around Moho depth at 
temperatures in excess of $\sim 800^{\circ} \mathrm{C}$ (Hansen et al., 2016). Beneath Hawaii, tectonic earthquakes thought to be caused by volcano loading and lithospheric flexure are known to occur as deep as $50 \mathrm{~km}$ along a long-lived tectonic fault zone (Wolfe et al., 2003). Recently, Inbal et al. (2016) located small earthquakes in southern California along the Newport-Inglewood fault below the Moho where temperatures are $\sim 800^{\circ} \mathrm{C}$, correlating with geochemical evidence of a fluid pathway from the mantle (Boles et al., 2015). Prieto et al. (2017) suggest that a mantle earthquake beneath the Wyoming craton at $75-\mathrm{km}$ depth occurred at temperatures of $750-850^{\circ} \mathrm{C}$ due to strain localization in the nominally ductile regime, $\sim 100 \mathrm{~km}$ away from the nearest volcanic center.

Laboratory experiments to determine rate-and-state friction laws for olivine are consistent with these earthquake observations, suggesting a temperature cut-off of $\sim 600^{\circ} \mathrm{C}$ at strain rates of $10^{-15}-10^{-14} \mathrm{~s}^{-1}$ for typical earthquakes, with the possibility that low-asperity stresses could extend this temperature to $\sim 800^{\circ} \mathrm{C}$ (Boettcher et al., 2007; King and Marone, 2012). Ohuchi et al. (2017) detected faulting associated with accelerated strain localization and localized heating in very fine-grained shear zones in dry dunite and extrapolate their laboratory observations to imply the possibility of faulting in the mantle lithosphere at temperatures up to $900^{\circ} \mathrm{C}$ at strain rates as low as $10^{-14} \mathrm{~s}^{-1}$. Thus, earthquake geothermometry suggests temperatures of $800^{\circ} \mathrm{C}$, or even $900^{\circ} \mathrm{C}$, as the cause of our observed 48-km seismicity cut-off.

There are no xenoliths reported from Harrat Lunayyir, but at Pleistocene Harrat Kishb, $150 \mathrm{~km}$ east of the MMN line (Fig. 1), spinel peridotites suggest temperatures of $910-970^{\circ} \mathrm{C}$ at $13-20 \mathrm{~kb}$ (McGuire \& Bohannon, 1989), corresponding to the entire depth range from the Moho to the LAB as imaged in this paper. Seismic wave-speeds, generally only a weak indication of temperature, suggest the mantle lithosphere beneath Harrat Lunayyir is at $800 \pm 200^{\circ} \mathrm{C}$ (Tang et al., 2016). Finally, our observation of seismograms with spectrogram peaks $>15 \mathrm{~Hz}$ (corresponding to short-wavelength S-waves, $<300 \mathrm{~m}$ ) (Fig. 6) indicates moderate to high $\mathrm{Q}$ in the source region. The sharp increase in seismic attenuation within olivine-dominated rocks at $\sim 1000^{\circ} \mathrm{C}$ (Artemieva et al., 2004) allows us to confidently exclude temperatures $\geq 1000^{\circ} \mathrm{C}$ at depths shallower than the seismicity cut-off beneath Harrat Lunayyir. We conclude that the ambient temperature at $48 \pm 2 \mathrm{~km}$ depth beneath Harrat Lunayyir is $850 \pm 50^{\circ} \mathrm{C}$.

In order to deduce the timing of lithospheric thinning beneath our study area, we assume the thermal structure beneath Harrat Lunayyir prior to any Red Sea rifting or plume impingement matches that in the center of the Arabian craton, which we derive from measured surface heat flow and heat production (measurement \#1, Fig 1; Gosnold, 2011) and assuming a mantle potential temperature of $1354^{\circ} \mathrm{C}$ (as petrologically estimated on the flanks of the MMN line; Camp \& Roobol, 1992). We solve for the depth to the LAB numerically and find the original depth to be 113-156 km, in accord with the modern 100-150 km values from S-wave receiver functions at the transition from the shield to the platform (Hansen et al., 2007). We use 1D finite-differences to model the temperature evolution beneath Harrat Lunayyir as and after the lithosphere is thinned to our observed $60 \mathrm{~km}$ thickness (Fig. 11). We assume the lithosphere is replaced from below by asthenosphere with an adiabatic gradient of $0.3^{\circ} \mathrm{C} / \mathrm{km}$, and we include depth-dependent radiogenic heat production and thermal conduction throughout model time and space. Our simple thermal model is insensitive to the duration of thinning so long as the duration is less than $\sim 70 \mathrm{Myr}$, because conduction has insufficient time to impact isotherms shallower than those being eroded from beneath.

Using the $350 \pm 50^{\circ} \mathrm{C}$ and $850 \pm 50^{\circ} \mathrm{C}$ isotherms as cut-off temperatures for seismicity within the uppercrust and mantle lithosphere, respectively, along with a present-day surface heat flow of $50 \pm 4 \mathrm{~mW} / \mathrm{m}^{2}$ (measurement \#4, Fig 1; Gosnold, 2011), we can place upper (14 Ma) and lower (10 Ma) bounds on how long ago the LAB must have reached its present, shallow depth of $60 \mathrm{~km}$. 


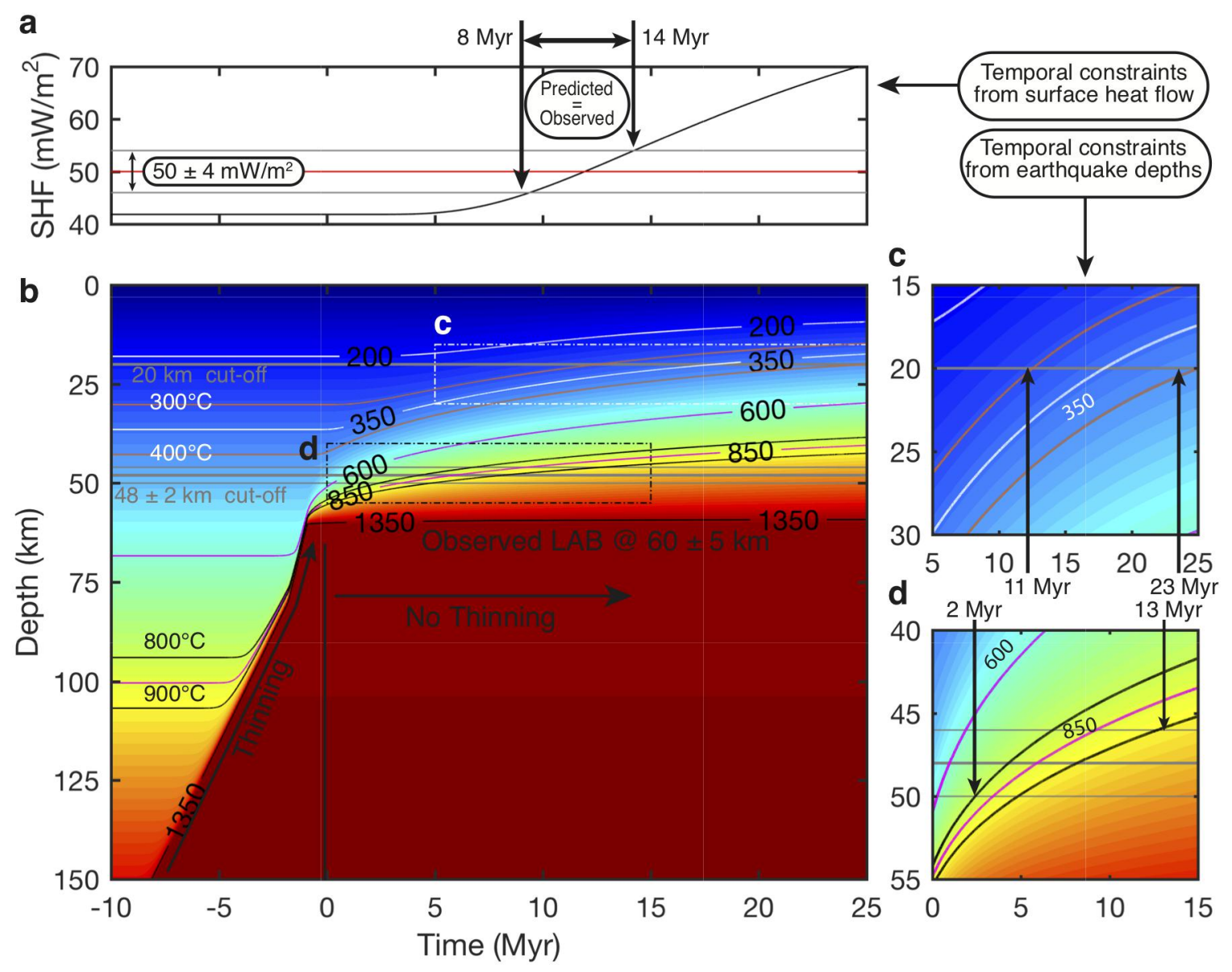

Figure 11. Thermal evolution model for the lithosphere beneath Harrat Lunayyir. Negative time is associated with the thinning process and positive time indicates the amount of time that has elapsed since thinning completed. a) Surface heat-flow (SHF) predicted by our model through time. Red line marks $50 \mathrm{~mW} / \mathrm{m}^{2}$ (modern heat-flow) and gray lines mark the $\pm 4 \mathrm{~mW} / \mathrm{m}^{2}$ bounds (Gosnold, 2011). b) Model run with an initial geothermal profile at $-10 \mathrm{Myr}$, matching current measurements from the center of the craton (i.e. Heat Flow 1, Fig. 1). c) Enlarged view of the timeframe in which the $350 \pm 50^{\circ} \mathrm{C}$ isotherm obtains a depth of $20 \mathrm{~km}$ (cut-off depth of the shallow seismicity). d) Enlarged view of the timeframe in which the $850 \pm 50^{\circ} \mathrm{C}$ isotherm obtains a depth of $48 \pm 2 \mathrm{~km}$ (cut-off depth of mantle seismicity). Thinning of the lithosphere stops with the LAB at 60 $\mathrm{km}$ at time $\mathrm{t}=0 \mathrm{Myr}$. Initial lithospheric thickness is the intersection of the conductive geotherm and the mantle adiabat. We thin the lithosphere to $80 \mathrm{~km}$ by basal erosion by $-1 \mathrm{Myr}$, and then thin the lithosphere very rapidly from 80 to $60 \mathrm{~km}$ from -1 to $0 \mathrm{Myr}$.

\section{Sensitivity of Thermal Modeling Parameters}

We tested the sensitivity of our thermal model to various parameter choices and assumptions. In our model of Figure 11 we used the commonly cited crustal conductivity of $2.51 \mathrm{~W} / \mathrm{m}^{\circ} \mathrm{C}$ (e.g. Gettings, 1982). Whittington et al. (2009) suggest thermal conductivity values as low as $\sim 2 \mathrm{~W} / \mathrm{m}^{\circ} \mathrm{C}$ in hot lower crust; however, using lower values of thermal conductivity raises the temperatures within the lithospheric mantle, so that we cannot match our observations of brittle-failure earthquakes within the lithospheric mantle unless such earthquakes can nucleate above $900^{\circ} \mathrm{C}$. 

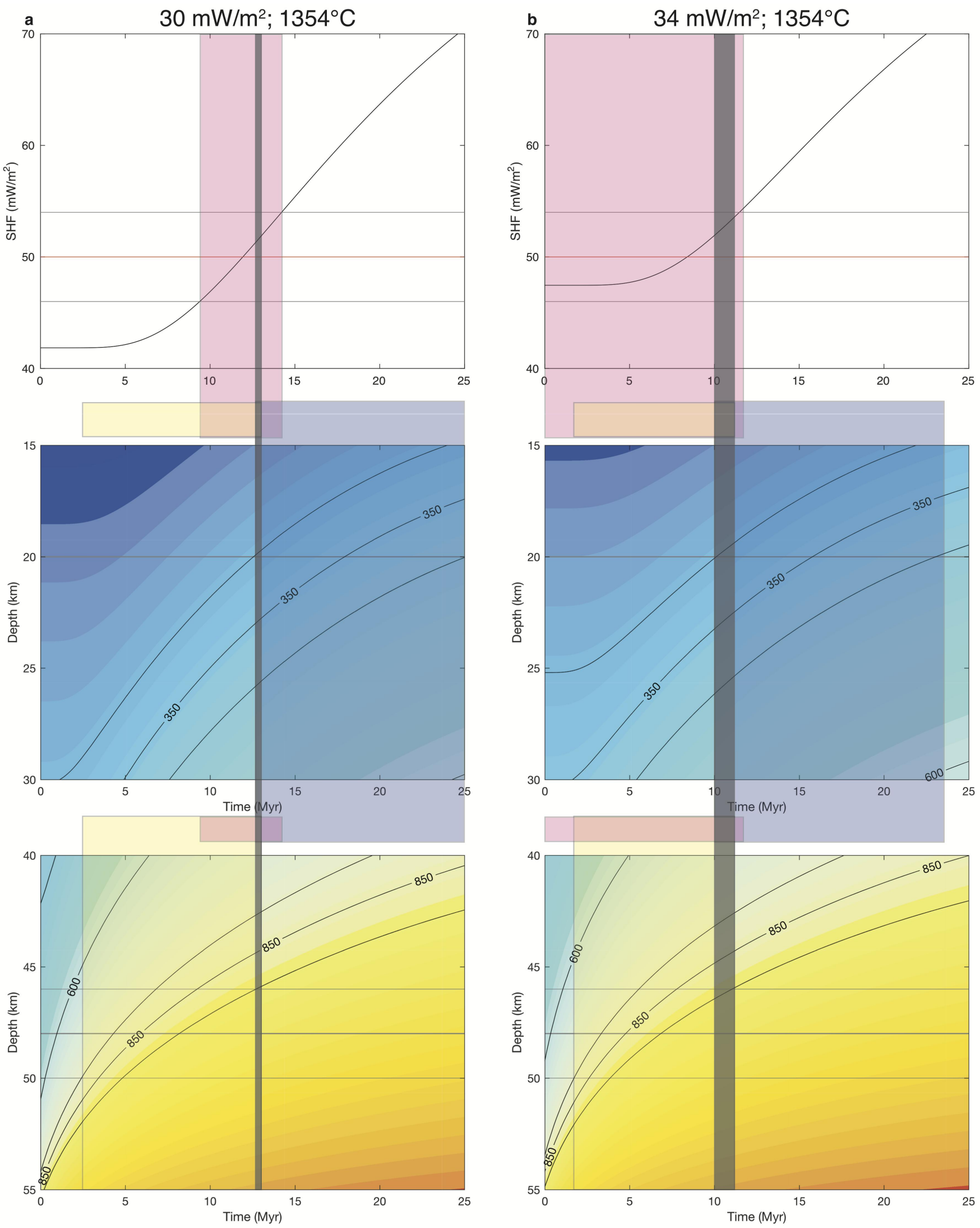

Figure 12. Comparison of thermal evolution models for mantle potential temperature of $1354^{\circ} \mathrm{C}$ and initial surface heat flow of (a) $30 \mathrm{~mW} / \mathrm{m}^{2}$ and (b) $34 \mathrm{~mW} / \mathrm{m}^{2}$. Top) Calculated surface heat flow from the model; red line marks $50 \mathrm{~mW} / \mathrm{m}^{2}$ (modern heat flow) and gray lines mark the $\pm 4 \mathrm{~mW} / \mathrm{m}^{2}$ bounds. Pink overlay marks the timeframe when the modeled heat flow values match the measured values. Middle) Thermal model at depths of $15-30 \mathrm{~km}$. Gray line at $20 \mathrm{~km}$ depth is the cut-off depth of the shallow seismicity. Blue overlay marks the 
timeframe when the base of the crustal seismicity $(20 \mathrm{~km})$ is within the temperature range of $350 \pm 50^{\circ} \mathrm{C}$. Bottom) Thermal model at depths of 40-55 km. Thick gray line is the $48 \mathrm{~km}$ cut-off of the mantle seismicity, with the $\pm 2 \mathrm{~km}$ bounds above and below it. Yellow overlay marks the timeframe when the base of the mantle seismicity $(48 \pm 2 \mathrm{~km})$ is within the temperature range of $850 \pm 50^{\circ} \mathrm{C}$. The vertical gray bar marks the timeframe where all the constraints overlap, denoting the preferred timing of lithospheric thinning to $60 \mathrm{~km}$.

In all our models the predicted initial surface heat-flow (SHF) (e.g. $42 \mathrm{~mW} / \mathrm{m}^{2}$ in Fig. 11a) exceeds the specified initial SHF $\left(30 \mathrm{~mW} / \mathrm{m}^{2}\right.$ for Fig. 11a) because the predicted SHF is calculated using the near-surface thermal conductivity actually measured at point $\# 4$ (Fig. 1$)\left(\mathrm{k}_{\text {surf }}=3.51 \mathrm{~W} / \mathrm{m}^{\circ} \mathrm{C}\right)$ since we are trying to match

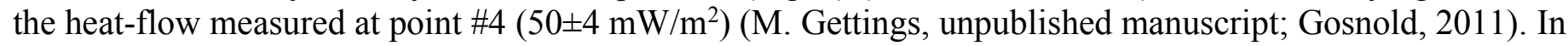
contrast the thermal calculations (e.g. Fig. $11 \mathrm{~b}$ ) use a bulk lithospheric thermal conductivity of $\mathrm{k}_{\text {avg }}=2.51$ $\mathrm{W} / \mathrm{m}^{\circ} \mathrm{C}$. Thus, the model shown in Figure 11 (identical to that in Fig. 12a) is chosen to have an initial SHF of $30 \mathrm{~mW} / \mathrm{m}^{2}$ for a conductivity of $2.51 \mathrm{~W} / \mathrm{m}^{\circ} \mathrm{C}$ and hence a near-surface thermal gradient of $12{ }^{\circ} \mathrm{C} / \mathrm{m}$. We use this near-surface thermal gradient $\left(12^{\circ} \mathrm{C} / \mathrm{m}\right)$ with $\mathrm{k}_{\text {surf }}=3.51 \mathrm{~W} / \mathrm{m}^{\circ} \mathrm{C}$ to calculate the predicted SHF plotted in Figure $11 \mathrm{a}\left(42 \mathrm{~mW} / \mathrm{m}^{2}\right)$.

We tested the sensitivity of our thermal model to a larger initial SHF of $34 \mathrm{~mW} / \mathrm{m}^{2}$ (the best estimate of Gettings \& Showail (1982) for measurement \#1 is $34 \pm 4 \mathrm{~mW} / \mathrm{m}^{2}$ ) (Fig. 12b), which predicts SHF of $48 \mathrm{~mW} / \mathrm{m}^{2}$ at 0 Myr model time due to the high shallow thermal conductivity. Because this predicted SHF of $48 \mathrm{~mW} / \mathrm{m}^{2}$ is already within the uncertainty of the observations at measurement \#4 (Fig. 12b), observed surface heat flow cannot place a lower limit on the age of lithospheric thinning. Nonetheless, the depths to the two brittle-ductile transitions still provide a strong constraint on the time of final thinning, 10-11 Ma for the initial heat flow of 34 $\mathrm{mW} / \mathrm{m}^{2}$ (Fig. 12b), very close to our previous result of 12-13 Ma for initial heat flow of $30 \mathrm{~mW} / \mathrm{m}^{2}$ (Fig. 12a).

The above results are all calculated for a mantle potential temperature of $1354^{\circ} \mathrm{C}$. If we instead use a mantle potential temperature of $1200^{\circ} \mathrm{C}$, lower than plausible, thinning must complete by $\sim 15$ Ma for initial heat flow of $30 \mathrm{~mW} / \mathrm{m}^{2}$ (Fig. 13a), or by $\sim 12 \mathrm{Ma}$ for initial heat flow of $34 \mathrm{~mW} / \mathrm{m}^{2}$ (Fig. 13b).

Thus, for the likely range of initial surface heat flow values and the mantle potential temperatures we can limit the time-frame of thinning to approximately $12 \pm 2 \mathrm{Ma}$.

Finally, we consider the consequences for our thermal modeling if we have incorrectly identified the prominent negative polarity (blue) converter in our common conversion-point cube (Fig. 3) as the LAB when in fact it could be a 'mid-lithospheric discontinuity' (MLD) (Aulbach et al., 2017). Beneath Harrat Lunayyir we have strong evidence from both body-wave and surface-wave tomography (e.g. Koulakov et al., 2016; Yao \& Mooney, 2017) that our converter is at an appropriate depth to be the LAB. However, it is not impossible that an MLD could be present at $60 \mathrm{~km}$ depth, if so, presumably above a deeper LAB invisible to receiver functions. Such an MLD would perhaps represent a live or frozen melt percolation front of carbonated peridotite representing solidus temperatures at $60 \mathrm{~km}$ depth in the range $1050-1150^{\circ} \mathrm{C}$ (that would correspond to equilibrium geotherms of $\sim 60-70 \mathrm{~mW} / \mathrm{m}^{2}$ ) (Aulbach et al., 2017; Dasgupta et al., 2013). We therefore ran our thermal model for a "mantle potential temperature" of $1050^{\circ} \mathrm{C}$ (Fig. 14) to show that even in this unlikely case the model results are not vastly dissimilar to those with our preferred parameters: thinning must complete by $\sim 18 \mathrm{Ma}$ for initial heat flow of $30 \mathrm{~mW} / \mathrm{m}^{2}$ (Fig. 14a), or by $\sim 14 \mathrm{Ma}$ for initial heat flow of $34 \mathrm{~mW} / \mathrm{m}^{2}$ (Fig. 14b). 

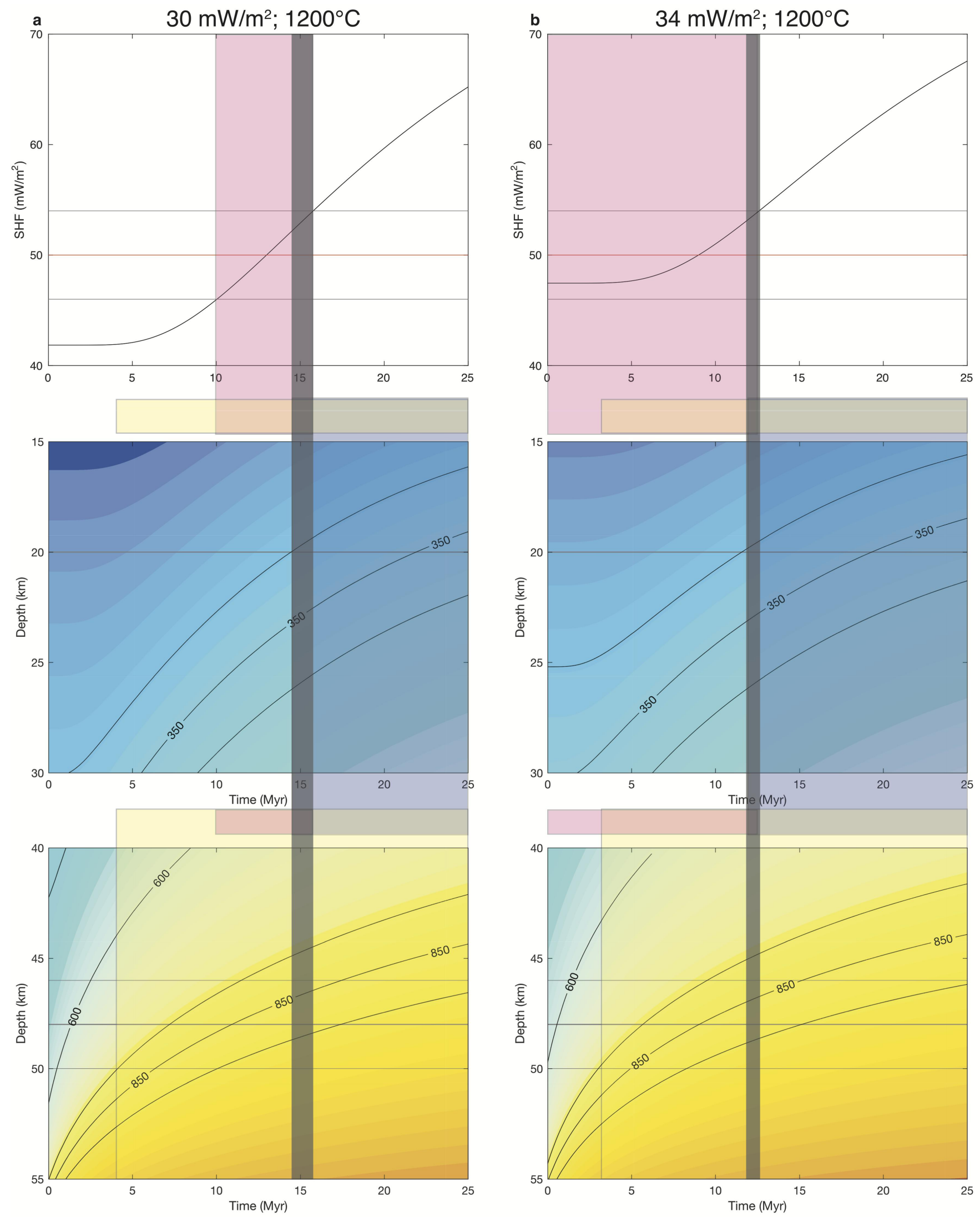

Figure 13. Comparison of thermal evolution models for mantle potential temperature of $1200^{\circ} \mathrm{C}$ and initial surface heat flow of (a) $30 \mathrm{~mW} / \mathrm{m}^{2}$ and (b) $34 \mathrm{~mW} / \mathrm{m}^{2}$. All bounds on the figure have the same definitions as those in Figure 12. 

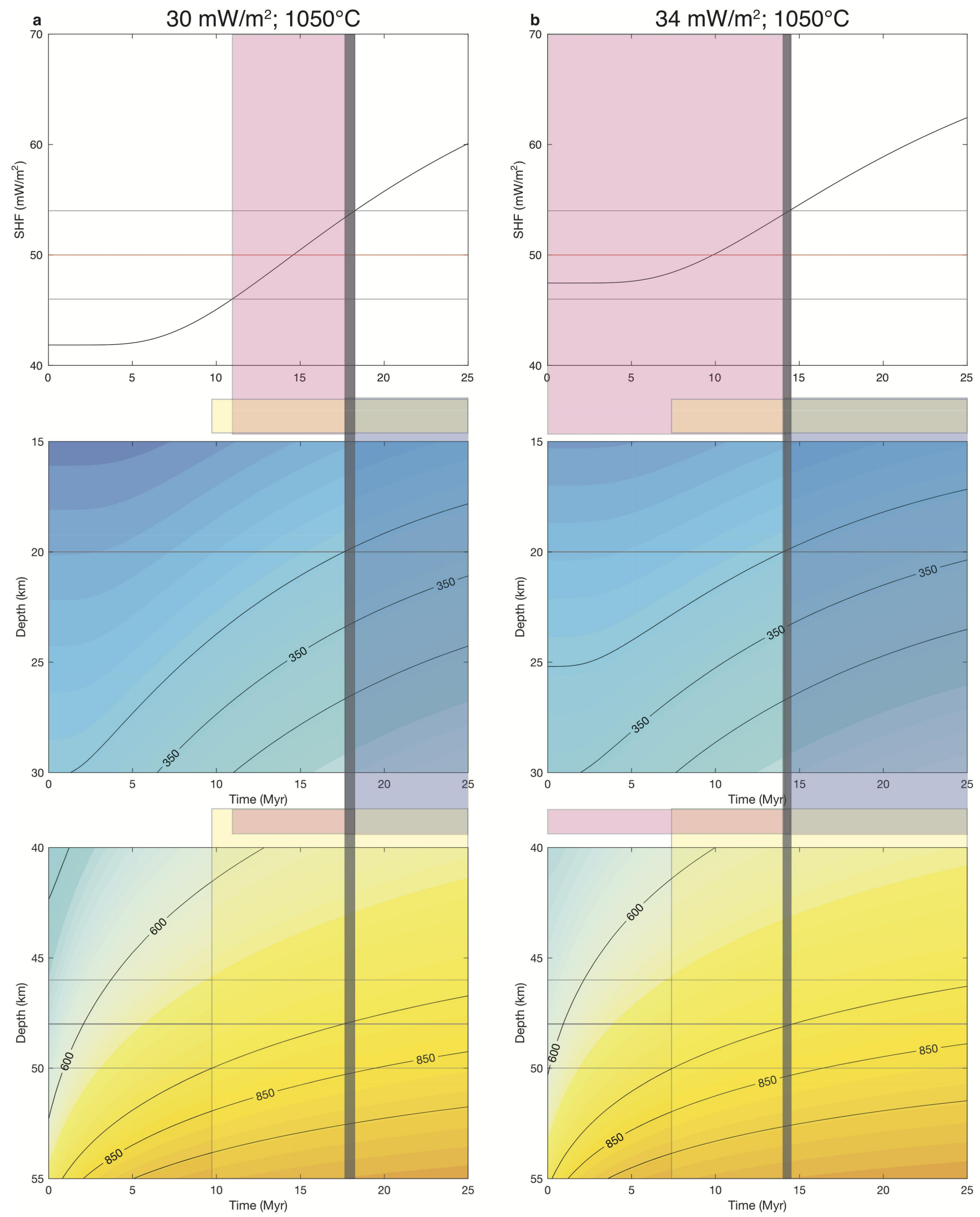

Figure 14. Thermal evolution models for mantle potential temperature of $1050^{\circ} \mathrm{C}$ and initial surface heat flow of (a) $30 \mathrm{~mW} / \mathrm{m}^{2}$ and (b) $34 \mathrm{~mW} / \mathrm{m}^{2}$.

In summary, our three independent thermal constraints (thinning must be recent enough that a brittle mantle lid still exists; thinning must be old enough that the crustal brittle-ductile transition has begun to shallow; 
and just right to match the observed surface heat-flow) provide a temporal constraint that is rather insensitive to a wide range of initial thermal conditions.

\section{Results and Discussion}

Figure 11d shows that by using the full range of geothermal models from Gosnold (2011), a temperature of $800^{\circ} \mathrm{C}\left(900^{\circ} \mathrm{C}\right)$ at $48 \pm 2 \mathrm{~km}$ depth is reached 2-5 Myr (4-11 Myr) after the lithosphere has thinned to $60 \mathrm{~km}$ depth. Although this time range is broad (2-11 Myr), it is nonetheless instructive. The youngest volcanotectonic event that can possibly have caused local lithospheric thinning, the onset of Harrat Lunayyir volcanism, is dated at $600 \mathrm{ka}$ (Duncan \& Al-Amri, 2013). However, if the lithosphere thinned to $60 \mathrm{~km}$ as recently as 600 $\mathrm{ka}$, the temperature at $48 \mathrm{~km}$ depth would now be only $600 \pm 50^{\circ} \mathrm{C}$ (geotherm at time $=0.6 \mathrm{Myr}$, Fig. $11 \mathrm{~b}$ ), and we would expect to see deeper earthquakes within the mantle lithosphere. The surface heat flow would also not have had time to increase from the initial $30 \mathrm{~mW} / \mathrm{m}^{2}$ to $50 \mathrm{~mW} / \mathrm{m}^{2}$. Hence, the onset of Harrat Lunayyir volcanism at $600 \mathrm{ka}$ was not the cause of local thinning of the lithosphere to the modern LAB depth.

The oldest magmatic event likely to have thinned the cratonic lithosphere was the impingement of Afar plume-head asthenosphere at $\sim 30 \mathrm{Ma}$ and the initial extension of the Red Sea by $25 \mathrm{Ma}$ (Stern \& Johnson, 2010; Bosworth, 2015). However, if the lithosphere beneath Harrat Lunayyir had thinned to its present $60 \mathrm{~km}$ as early as $25 \mathrm{Ma}$, the temperature at $48 \mathrm{~km}$ depth would now be $1050 \pm 50^{\circ} \mathrm{C}$ (geotherm at time $=25 \mathrm{Myr}$, Fig. $11 \mathrm{~b}$ ), and we would not have brittle-failure earthquakes at that depth nor most likely anywhere in the mantle lid. Furthermore, we would expect high seismic attenuation, inconsistent with our observation of high-frequency earthquakes, as well as significantly elevated surface heat flow values of $\sim 70 \mathrm{~mW} / \mathrm{m}^{2}$, far higher than observed (Fig. 11a). Hence, early Red Sea extension cannot have thinned the Arabian lithosphere to its present $60-\mathrm{km}$ thickness beneath Harrat Lunayyir.

The implication of the brittle-failure mantle earthquakes is that a second phase of lithospheric thinning, as well as uplift and likely extension, must have taken place in the Middle and/or Late Miocene. The younger harrat volcanism along the MMN line began at $12 \mathrm{Ma}$ (Camp \& Roobol, 1992) including other harrats at the latitude of Harrat Lunayyir (e.g., Harrat Kura, 11 Ma; Stern \& Johnson, 2010). Apatite and zircon (U-Th)/He ages from the rift margin across Harrats Lunayyir and Khaybar (Fig. 1) suggest renewed extension between 15$12 \mathrm{Ma}$ (Szymanski et al., 2016). If the Arabian lithosphere thinned to $60 \mathrm{~km}$ at $12 \mathrm{Ma}$, then the coldest of our initial geothermal profiles would only now have reached the highest permissible temperature $\left(900^{\circ} \mathrm{C}\right)$ at the shallowest permitted seismic cut-off depth $(46 \mathrm{~km})$. Our observed earthquake cut-off depth in the mantle is only defined by a relatively short duration of recording; however, if we had observed deeper earthquakes, it would require more recent thinning of the lithosphere. Our choice of a limiting temperature of $850 \pm 50^{\circ} \mathrm{C}$ is higher than the $600-700^{\circ} \mathrm{C}$ that is often considered the cut-off of brittle behavior in the upper mantle, but using the lower temperatures would only permit a far more recent thinning of the lithosphere. Hence both scenarios (deeper earthquakes; lower temperature limit) would imply that the lithosphere is even more out of equilibrium and would more strongly support two-phase rifting.

The cut-off in crustal seismicity at $20 \mathrm{~km}$ depth is far less diagnostic of the timing of the completion of lithospheric thinning because the $350 \pm 50^{\circ} \mathrm{C}$ isotherms in our models are so much flatter than the $850 \pm 50^{\circ} \mathrm{C}$ isotherms (Fig. 11c). Even modest uncertainty in the appropriate cut-off isotherm that arises due to crustal lithologic variability (Magistrale \& Zhou, 1996) leads to significant uncertainty in the timing of crustal heating. However, our initial geothermal models, prior to thinning, place the $350 \pm 50^{\circ} \mathrm{C}$ isotherms at $\sim 30-45 \mathrm{~km}$ depth, clearly deeper than our mid-crustal cut-off in seismicity. Considering the full range of acceptable initial heatflow and heat-production estimates (Gosnold, 2011) permits a crustal cut-off in seismicity at $20 \mathrm{~km}$ depth. Hence, we prefer models in which shallowing of the LAB is sufficiently far in the past (before $\sim 11 \mathrm{Ma}$; Fig. 11c) for mid-crustal temperatures to be sufficiently elevated.

Acceptable solutions using the mean initial geothermal parameters for the time at which lithospheric thinning reduced the lithosphere to the observed $60 \mathrm{~km}$ thickness must fit our heat flow constraints (8-14 Ma; Fig. 11a), the maximum depth of crustal earthquakes (11-23 Ma; Fig. 11c), and the maximum depth of mantle earthquakes (2-13 Ma; Fig. 11d). Therefore, acceptable solutions must be at least $11 \mathrm{Ma}$, but can be no older than $13 \mathrm{Ma}$. Thinning ages $<11 \mathrm{Ma}$ would imply that the crustal seismicity is limited to regions at 
temperatures $<300^{\circ} \mathrm{C}$. (implausible in anhydrous Proterozoic basement; Chen \& Molnar, 1983). Thinning ages $>13$ Ma would imply that the mantle earthquakes occur at temperatures in excess of $900^{\circ} \mathrm{C}$, hotter than previously observed or proposed (Chen \& Molnar, 1983; McKenzie et al., 2005). Tests of model sensitivity to various thermal parameters suggest that thinning completed at $\sim 12 \pm 2 \mathrm{Ma}$.

Although our modeling cannot formally exclude continuous thinning from $30 \mathrm{Ma}$ (or earlier) to $\sim 12 \mathrm{Ma}$, this 'continuous' scenario offers no ready explanation for the hiatus in magmatism and extension from 20-15 Ma (Camp \& Roobol, 1992; Stern \& Johnson, 2010). Indeed, a common feature of continental rifts that progress to ocean spreading is that they evolve in two separate phases (Brune et al., 2016), where initially strong lithosphere is slowly thinned and dynamically weakened through rift-induced heating, initiating a second and much faster phase. The second, faster rifting phase usually begins $\sim 10 \mathrm{Myr}$ before inception of breakup of the continental lithosphere and persists until complete plate separation is achieved. The second stage is not observed in failed rifts, where conductive cooling strengthens the lithosphere faster than it can be dynamically weakened, leading to rift failure (Brune et al., 2016).

In our preferred scenario the first stage of extension, uplift, and magmatism between 30-20 Ma was contemporaneous with modest lithospheric thinning but failed to rupture the continent and represents the slow phase of rift-evolution. The thermal constraints are, unfortunately, insensitive to the intermediate lithospheric thickness achieved during the first stage given the timescale at which heat diffuses. The change in plate boundary conditions in the middle Miocene (i.e., the onset of full ocean spreading in the Gulf of Aden and of the onset of Dead Sea transform motion) allowed rotation and an increase of the extensional stresses along the Red Sea rift to be more favorable for the second-stage of rifting (Reilinger \& McClusky, 2011). Lithospheric thickness beneath Harrat Lunayyir decreased to $60 \mathrm{~km}$ between 15-10 Ma, largely by replacement of the lithosphere with asthenosphere, initiating the younger harrat volcanism. This second phase of lithospheric thinning must then have essentially stopped beneath Harrat Lunayyir to preserve the observed gap in seismicity between $48 \mathrm{~km}$ and the $60-\mathrm{km}$ deep LAB. We suggest thinning beneath Harrat Lunayyir concluded as rifting became more focused within the Red Sea (cf. Szymanski et al., 2016).

\section{Conclusions}

Our seismic imaging locates the Moho beneath Harrat Lunayyir at $38 \pm 2 \mathrm{~km}$ depth and the LAB at $60 \pm$ $5 \mathrm{~km}$ depth, despite being located within a Precambrian shield. Observations of earthquakes within the lithospheric mantle beneath Harrat Lunayyir span the entire time period for which a suitably dense seismic array was active (i.e. since August 2010). During 2014, there were 64 high-frequency "brittle-failure" type earthquakes whose hypocenters, well constrained to the upper $10 \mathrm{~km}$ of the lithospheric mantle (depths of 42$48 \mathrm{~km}$ ), lie on a plane striking $\sim \mathrm{N} 103^{\circ} \mathrm{E}$ and dipping $\sim 43^{\circ} \mathrm{S}$, located roughly $30 \mathrm{~km}$ to the southeast of the 2009 dike intrusion. These brittle-failure earthquakes are likely caused by melt migration within the lithospheric mantle. The existence of these brittle-failure earthquakes constrains the temperature at $48 \pm 2 \mathrm{~km}$ depth to be $850 \pm 50^{\circ} \mathrm{C}$, which in turn requires the LAB to have reached its present shallow level in middle Miocene time (ca. $12 \pm 2 \mathrm{Ma}$ ). Our results are consistent with a two-stage model for the evolution of continental rifting, as suggested by Brune et al. (2016) globally and as proposed by Szymanski et al. (2016) for the Red Sea rift. Our identification of high-frequency earthquakes in the shallow lithospheric mantle provides a powerful means of estimating the thermal structure of the lithosphere and consequently the timing of continental rifting in the Red Sea. 


\section{Acknowledgements}

We thank Jeanne Hardebeck, David Shelly and Tom Parsons for invaluable comments during the USGS internal review; Gary Chulick and David Hill for informal review comments on this manuscript; and Bernard Chouet and Katie Keranen for insightful discussions. We would like to thank Derek Keir and an anonymous reviewer for their thorough reviews and excellent suggestions that have substantially improved the manuscript.

\section{References Cited}

Ágústsson, K., \& Flóvenz, Ó. G. (2005). The thickness of the seismogenic crust in Iceland and its implications for geothermal systems. In Proceedings of the World Geothermal Congress (pp. 24-29).

Almazroui, M., Nazrul Islam, M., Athar, H., Jones, P. D., \& Rahman, M. A. (2012). Recent climate change in the Arabian Peninsula: annual rainfall and temperature analysis of Saudi Arabia for 19782009. International Journal of Climatology, 32(6), 953-966. doi:10.1002/joc.3446

Artemieva, I. M., Billien, M., Lévêque, J. J., \& Mooney, W. D. (2004). Shear wave velocity, seismic attenuation, and thermal structure of the continental upper mantle. Geophysical Journal International, 157(2), 607-628. doi:10.1111/j.1365-246X.2004.02195.X

Aulbach, S., Massuyeau, M., \& Gaillard, F. (2017). Origins of cratonic mantle discontinuities: A view from petrology, geochemistry and thermodynamic models. Lithos, 268, 364-382. doi:10.1016/j.lithos.2016.11.004

Boettcher, M. S., Hirth, G., \& Evans, B. (2007). Olivine friction at the base of oceanic seismogenic zones. Journal of Geophysical Research: Solid Earth, 112(B1). doi:10.1029/2006JB004301

Boles, J. R., Garven, G., Camacho, H., \& Lupton, J. E. (2015). Mantle helium along the Newport-Inglewood fault zone, Los Angeles basin, California: A leaking paleo-subduction zone. Geochemistry, Geophysics, Geosystems, 16(7), 2364-2381. doi:10.1002/2015GC005951

Bosworth, W. (2015). Geological evolution of the Red Sea: historical background, review, and synthesis. In The Red Sea (pp. 45-78). Springer Berlin Heidelberg. doi:10.1007/978-3-662-45201-1_3

Brune, S., Williams, S. E., Butterworth, N. P., \& Müller, R. D. (2016). Abrupt plate accelerations shape rifted continental margins. Nature, 536, 201-204. doi:10.1038/nature18319

Camp, V. E., \& Roobol, M. J. (1992). Upwelling asthenosphere beneath western Arabia and its regional implications. Journal of Geophysical Research: Solid Earth, 97(B11), 15255-15271. doi:10.1029/92JB00943

Chen, W. P., \& Molnar, P. (1983). Focal depths of intracontinental and intraplate earthquakes and their implications for the thermal and mechanical properties of the lithosphere. Journal of Geophysical Research: Solid Earth, 88(B5), 4183-4214. doi:10.1029/JB088iB05p04183

Chouet, B. A., \& Matoza, R. S. (2013). A multi-decadal view of seismic methods for detecting precursors of magma movement and eruption. Journal of Volcanology and Geothermal Research, 252, 108-175. doi:10.1016/j.jvolgeores.2012.11.013 
Dasgupta, R., Mallik, A., Tsuno, K., Withers, A.C., Hirth, G. and Hirschmann, M.M., 2013. Carbon-dioxiderich silicate melt in the Earth's upper mantle. Nature, 493(7431), 211. doi:10.1038/nature11731

Duncan, R. A., \& Al-Amri, A. M. (2013). Timing and composition of volcanic activity at Harrat Lunayyir, western Saudi Arabia. Journal of Volcanology and Geothermal Research, 260, 103-116. doi:10.1016/j.jvolgeores.2013.05.006

Earle, P. S., \& Shearer, P. M. (1994). Characterization of global seismograms using an automatic-picking algorithm. Bulletin of the Seismological Society of America, 84(2), 366-376.

Frohlich, C., Gan, W., \& Herrmann, R. B. (2015). Two deep earthquakes in Wyoming. Seismological Research Letters, 86(3), 810-818. doi:10.1785/0220140197

Gettings, M. E. (1982). Heat-flow measurements at shot points along the 1978 Saudi Arabia seismic deeprefraction line; Part II, Discussion and interpretation. US Geological Survey. Open File report No. 82794, pp. 40.*

Gettings, M.E. (unpublished manuscript). Estimates of the Thermal State of the Arabian Plate from Heat flow, Uplift, and Volcanism of Western Saudi Arabia, pp. 41.*

Gettings, M.E., \& Showail, A. (1982). Heat-flow measurements at shot points along the 1978 Saudi Arabia seismic deep-refraction line; Part I, Results of the measurements. US Geological Survey. Open File report No. 82-793, pp. 98 . *

Girdler, R. W., \& Styles, P. (1974). Two stage Red Sea floor spreading. Nature, 247(5435), 7. doi:10.1038/247007a0

Gosnold, W. (2011). The global heat flow database. The International Heat Flow Commission: https://www.heatflow.und.edu:80/data.html. Archived by "Internet Archive Wayback Machine": https://web.archive.org/web/20170919200320/http:/www.heatflow.und.edu:80/data.html

Hansen, S. E., Rodgers, A. J., Schwartz, S. Y., \& Al-Amri, A. M. (2007). Imaging ruptured lithosphere beneath the Red Sea and Arabian Peninsula. Earth and Planetary Science Letters, 259(3), 256-265. doi:10.1016/j.eps1.2007.04.035

Hansen, S. M., Schmandt, B., Levander, A., Kiser, E., Vidale, J. E., Abers, G. A., \& Creager, K. C. (2016). Seismic evidence for a cold serpentinized mantle wedge beneath Mount St Helens. Nature communications, 7. doi:10.1038/ncomms13242

Hill, D. P., \& Prejean, S. (2005). Magmatic unrest beneath mammoth mountain, California. Journal of Volcanology and GeothermalResearch, 146(4), 257-283. doi:10.1016/j.jvolgeores.2005.03.002

Inbal, A., Ampuero, J. P., \& Clayton, R. W. (2016). Localized seismic deformation in the upper mantle revealed by dense seismic arrays. Science, 354(6308), 88-92. doi:10.1126/science.aaf1370

Kennett, B. L. N. (1991). IASPEI 1991 seismological tables. Terra Nova, 3(2), 122-122. doi:10.1111/j.13653121.1991.tb00863.x

Kind, R., Yuan, X., \& Kumar, P. (2012). Seismic receiver functions and the lithosphere-asthenosphere boundary. Tectonophysics, 536, 25-43. doi:10.1016/j.tecto.2012.03.005 
King, D. S. H., \& Marone, C. (2012). Frictional properties of olivine at high temperature with applications to the strength and dynamics of the oceanic lithosphere. Journal of Geophysical Research: Solid Earth, 117(B12). doi:10.1029/2012JB009511

Klein, F. W. (2002). User's guide to HYPOINVERSE-2000, a Fortran program to solve for earthquake locations and magnitudes (No. 2002-171). US Geological Survey.

Koulakov, I., Burov, E., Cloetingh, S., El Khrepy, S., Al-Arifi, N., \& Bushenkova, N. (2016). Evidence for anomalous mantle upwelling beneath the Arabian Platform from travel time tomography inversion. Tectonophysics, 667, 176-188. doi:10.1016/j.tecto.2015.11.022

Langston, C. A. (1979). Structure under Mount Rainier, Washington, inferred from teleseismic body waves. Journal of Geophysical Research: Solid Earth, 84(B9), 4749-4762. doi:10.1029/JB084iB09p04749

Ligorria, J. P., \& Ammon, C. J. (1999). Iterative deconvolution and receiver-function estimation. Bulletin of the seismological Society of America, 89(5), 1395-1400.

Magistrale, H., \& Zhou, H. W. (1996). Lithologic control of the depth of earthquakes in southern California. Science, 273(5275), 639. doi:10.1126/science.273.5275.639

McCausland, W. A., Gunawan, H., White, R. A., Indrastuti, N., Patria, C., Suparman, Y., ... \& Hendrasto, M. (2017). Using a process-based model of pre-eruptive seismic patterns to forecast evolving eruptive styles at Sinabung Volcano, Indonesia. Journal of Volcanology and Geothermal Research. doi:10.1016/j.jvolgeores.2017.04.004

McGuire, A. V., \& Bohannon, R. G. (1989). Timing of mantle upwelling: evidence for a passive origin for the Red Sea rift. Journal of Geophysical Research: Solid Earth, 94(B2), 1677-1682. doi:10.1029/JB094iB02p01677

McKenzie, D., Jackson, J., \& Priestley, K. (2005). Thermal structure of oceanic and continental lithosphere. Earth and Planetary Science Letters, 233(3), 337-349. doi:10.1016/j.epsl.2005.02.005

Mechie, J., Ben-Avraham, Z., Weber, M. H., Götze, H. J., Koulakov, I., Mohsen, A., \& Stiller, M. (2013). The distribution of Moho depths beneath the Arabian plate and margins. Tectonophysics, 609, 234-249. doi:10.1016/j.tecto.2012.11.015

Mooney, W. D., Gettings, M. E., Blank, H. R., \& Healy, J. H. (1985). Saudi Arabian seismic-refraction profile: a traveltime interpretation of crustal and upper mantle structure. Tectonophysics, 111(3-4), 173-246. doi:10.1016/0040-1951(85)90287-2

Mooney, W. D., Ritsema, J., \& Hwang, Y. K. (2012). Crustal seismicity and the earthquake catalog maximum moment magnitude $\left(\mathrm{M}_{\mathrm{cmax}}\right)$ in stable continental regions (SCRs): Correlation with the seismic velocity of the lithosphere. Earth and planetary science letters, 357, 78-83. doi:10.1016/j.eps1.2012.08.032

Ohuchi, T., Lei, X., Ohfuji, H., Higo, Y., Tange, Y., Sakai, T., ... \& Irifune, T. (2017). Intermediate-depth earthquakes linked to localized heating in dunite and harzburgite. Nature Geoscience. doi:10.1038/ngeo3011

Omar, G. I., \& Steckler, M. S. (1995). Fission track evidence on the initial rifting of the Red Sea: two pulses, no propagation. Science, 270(5240), 1341-1344. doi:10.1126/science.270.5240.1341 
Pallister, J. S., McCausland, W. A., Jónsson, S., Lu, Z., Zahran, H. M., El Hadidy, S., ... \& Moufti, M. R. (2010). Broad accommodation of rift-related extension recorded by dyke intrusion in Saudi Arabia. Nature Geoscience, 3(10), 705. doi:10.1038/ngeo966

Park, Y., Nyblade, A. A., Rodgers, A. J., \& Al-Amri, A. (2008). S wave velocity structure of the Arabian Shield upper mantle from Rayleigh wave tomography. Geochemistry, Geophysics, Geosystems, 9(7). doi:10.1029/2007GC001895

Prieto, G. A., Froment, B., Yu, C., Poli, P., \& Abercrombie, R. (2017). Earthquake rupture below the brittleductile transition in continental lithospheric mantle. Science Advances, 3(3), e1602642. doi:10.1126/sciadv.1602642

Recktenwald, G. W. (2004). Finite-difference approximations to the heat equation. Mechanical Engineering, 10, $1-27$.

Reilinger, R., \& McClusky, S. (2011). Nubia-Arabia-Eurasia plate motions and the dynamics of Mediterranean and Middle East tectonics. Geophysical Journal International, 186(3), 971-979. doi:10.1111/j.1365246X.2011.05133.X

Shelly, D. R., \& Hill, D. P. (2011). Migrating swarms of brittle-failure earthquakes in the lower crust beneath Mammoth Mountain, California. Geophysical Research Letters, 38(20). doi:10.1029/2011GL049336

Schulte-Pelkum, V., Monsalve, G., Sheehan, A. F., Shearer, P., Wu, F., \& Rajaure, S. (2019). Mantle earthquakes in the Himalayan collision zone. Geology. doi:10.1130/G46378.1

Sloan, R. A., \& Jackson, J. A. (2012). Upper-mantle earthquakes beneath the Arafura Sea and south Aru Trough: Implications for continental rheology. Journal of Geophysical Research: Solid Earth, 117(B5). doi:10.1029/2011JB008992

Stern, R. J., \& Johnson, P. (2010). Continental lithosphere of the Arabian Plate: a geologic, petrologic, and geophysical synthesis. Earth-Science Reviews, 101(1), 29-67. doi:10.1016/j.earscirev.2010.01.002

Stoeser, D. B., \& Camp, V. E. (1985). Pan-African microplate accretion of the Arabian Shield. Geological Society of America Bulletin, 96(7), 817-826. doi:10.1130/0016-7606(1985)96<817:PMAOTA>2.0.CO;2

Szymanski, E., Stockli, D. F., Johnson, P. R., \& Hager, C. (2016). Thermochronometric evidence for diffuse extension and two-phase rifting within the Central Arabian Margin of the Red Sea Rift. Tectonics, 35(12), 2863-2895. doi:10.1002/2016TC004336

Tang, Z., Julià, J., Zahran, H., \& Mai, P. M. (2016). The lithospheric shear-wave velocity structure of Saudi Arabia: Young volcanism in an old shield. Tectonophysics, 680, 8-27. doi:10.1016/j.tecto.2016.05.004

Turcotte, Donald L., and Gerald Schubert. Geodynamics. 2nd ed., Cambridge, Cambridge University Press, 2002. doi:10.1017/CBO9780511807442

Waldhauser, F. (2001). hypoDD--A Program to Compute Double-Difference Hypocenter Locations (hypoDD version 1.0-03/2001). US Geol. Surv. Open-File Rept. 01, 113. 
White, R. S., Drew, J., Martens, H. R., Key, J., Soosalu, H., \& Jakobsdóttir, S. S. (2011). Dynamics of dyke intrusion in the mid-crust of Iceland. Earth and Planetary Science Letters, 304(3), 300-312. doi:10.1016/j.eps1.2011.02.038

Whittington, A. G., Hofmeister, A. M., \& Nabelek, P. I. (2009). Temperature-dependent thermal diffusivity of the Earth's crust and implications for magmatism. Nature, 458(7236), 319. doi:10.1038/nature07818

Wolfe, C. J., Okubo, P. G., \& Shearer, P. M. (2003). Mantle fault zone beneath Kilauea volcano, Hawaii. Science, 300(5618), 478-480. doi:10.1126/science.1082205

Yang, Z., \& Chen, W. P. (2010). Earthquakes along the East African Rift System: A multiscale, system-wide perspective. Journal of Geophysical Research: Solid Earth, 115(B12). doi:10.1029/2009JB006779

Yao, Z., Mooney, W. D., Zahran, H. M., \& Youssef, S. E. H. (2017). Upper mantle velocity structure beneath the Arabian Shield from Rayleigh surface wave tomography and its implications. Journal of Geophysical Research: Solid Earth. doi:10.1002/2016JB013805

Youssef, S. E. H. (2015). Seismicity and seismotectonic setting of the Red Sea and adjacent areas. In The Red Sea (pp. 151-159). Springer Berlin Heidelberg. doi:10.1007/978-3-662-45201-1_8 